\title{
The Role of Values in Nietzsche's Metaphilosophy
}

\author{
Paul S. Loeb ${ }^{1}$
}

Abstract

The goal of this essay is to show how we might gain new insight into the meaning of Nietzsche's metaphilosophical lessons at the start of Beyond Good and Evil. Maudemarie Clark's interpretation of these lessons is prima facie plausible and has gained widespread acceptance in the Anglophone community of Nietzsche scholars. According to this reading, Nietzsche thinks that philosophers cannot belp but project their preferred values into their theories of the world and he thinks that this is true of his own theory of the world as will to power. I argue that there are severe problems with Clark's supporting textual evidence and that we should therefore reconsider how we usually think today about the role of values in Nietzsche's conception of philosophy and about the epistemic status that he grants to his own philosophical theories.

\section{Introduction}

In this essay I challenge the widely accepted interpretative idea, argued most prominently by Maudemarie Clark, that Nietzsche begins Beyond Good and Evil by teaching that philosophers, including himself, cannot help but project themselves and their values into all of reality. According to this idea, Nietzsche encourages philosophers, who are valuecreators and value-legislators, to be true to this natural self-affirming impulse and to interpret reality from the viewpoint of their own values. All he requires is that they project values that are life-affirming and that they honestly acknowledge the noncognitive status of their resulting theories. In fact, this is just what Nietzsche is doing with his own theory of reality as will to power.

Through a close examination of the relevant opening sections in BGE, I argue that this is a mistaken interpretation of Nietzsche's metaphilosophical lessons. In these sections, Nietzsche is actually criticizing past philosophers for committing a falsifying cognitive error when they projected themselves and their values into all of reality. This is the error that Aristotle called the composition fallacy, namely, attributing to a whole the properties that belong to a small and atypical subset of the whole. It does not matter what kind of values they were projecting or that they acknowledged they were doing this. Drawing on

\footnotetext{
${ }^{1}$ Paul S. Loeb, University of Puget Sound, United States. E-mail: loeb@pugetsound.edu.

Paul S. Loeb is Emeritus Professor of Philosophy at the University of Puget Sound. He is the author of The Death of Nietzsche's Zarathustra (Cambridge University Press, 2010), the co-editor of Nietzsche's Metaphilosophy (Cambridge University Press, 2019) and Nietzsche's Thus Spoke Zarathustra: A Critical Guide (Cambridge University Press, 2022), and the co-translator of Unpublished Fragments from the Period of Thus Spoke Zarathustra, Volumes 14 and 15 in The Complete Works of Friedrich Nietzsche (Stanford University Press, 2019 and 2022).
} 
Nietzsche's famous "Let us beware!" manifesto in Gay Science 109, I argue further that he is actually advising future philosophers to subtract previous anthropomorphic projections so as to counter this falsifying cognitive error and help reveal what the world as a whole is really like. Indeed, I claim, Nietzsche employs just this interpretive method in order to derive his own theory of cosmological will to power. However, this new method should not be confused with the approach of Kantian philosophers who aim to understand what the world is like "in itself," that is, independently of any human perspective or interpretation. Nor should it be understood as a disinterested expression of the will to truth for its own sake. Instead, whereas past philosophers strove to increase their feeling of intellectual power by idealizing the universe, Nietzsche thinks that he, and future philosophers following his lead, will succeed in gaining far more intellectual power if they aim to understand the universe as it actually is.

\section{Clark's Interpretation}

Over the course of nearly four decades, Maudemarie Clark has argued that Nietzsche is advancing three closely related metaphilosophical lessons in these opening sections of Beyond Good and Evil:

(1) BGE 5-6: Philosophers cannot help but project their personal prejudices and ideals into their theories of reality. ${ }^{2}$

(2) BGE 9: Philosophers cannot help but construct their pictures of the world in their own image and in the image of their preferred values and ideals. ${ }^{3}$

(3) BGE 22: Philosophers cannot help but interpret nature in terms of their preferred values and ideals. ${ }^{4}$

Although it might appear that Nietzsche is criticizing philosophers for these idealizing and self-glorifying tendencies, Clark argues that he is actually encouraging these tendencies. This is how she summarizes her thesis in her most recent discussion:

Because Nietzsche believes that interpretations of the world in terms of values provide something that is as important as truth, he wants the philosophy of the future to preserve this [value-creating and value-legislating] function of traditional philosophy. He does not, however, wish to preserve two aspects of the way in which previous philosophers have gone about this task: the lack of courage evident in their failure to recognize that they were reading values into the world rather than discovering truth, and the particular [ascetic] values they read into the world. $(2019, \$ 6)^{5}$

\footnotetext{
${ }^{2}$ Clark 1983, 464; 1990, 219, 239; 2000, 126; Clark and Dudrick 2012, 65-68, 143-155; Clark and Dudrick 2014a, 343; Clark $2019, \$ 6$.

${ }^{3}$ Clark 1983, 463; 1990, 220-221; 2000, 126; Clark and Dudrick 2012, 65-66, 142-143, 146-148; Clark 2015, 257; Clark and Dudrick 2014a, 342-343; Clark 2019, \$\$6, 11.

${ }^{4}$ Clark 1983, 465-467; 1990, 221-223; 2000, 124-125, 130; Clark and Dudrick 2012, 223-229; Clark 2019, \$\$6, 11.

${ }^{5}$ Here is the context of the quote that explains the bracketed terms I have inserted: "If philosophers are to remain true to the calling of philosophy and not squander their inheritance, they must create new values and not continue merely to codify and structure the value legislations of ascetic priests. To create new values, however, it will be necessary for philosophers to overcome the ascetic faith that truth is more important than anything else, for truth is not sufficient support for any ideal."
} 
Accordingly, she claims, Nietzsche courageously lets us know that he recognizes that his own theory of the world as will to power is not a discovery of the truth but rather a projection of his own life-affirming values: "The cosmological doctrine of the will to power is the kind of construction of the world Nietzsche claims philosophers have selfdeceptively engaged in. The difference is that Nietzsche knows perfectly well it is not the truth and that he gives us the clues we need to figure out that it is actually a projection of his life-affirming (and self-affirming) ideal" (1990, 240).

Here, then, is the central thread of Clark's exegetical argument, in which she cites the textual details of Nietzsche's presentation of each of the metaphilosophical lessons offered in these opening sections of BGE and claims that he intended to illustrate these lessons with his own theory of cosmological will to power:

(1') BGE 5-6: "Nietzsche seeks to display the courage and self-knowledge to warn us that his [cosmological] doctrine [of the will to power] is 'a desire of the heart that has been filtered and made abstract,' a 'prejudice' he has baptized 'truth"' (1990, 219).

(2') BGE 9: "Since Nietzsche tells us that philosophy itself is 'the most spiritual will to power'-precisely because it reads its values into the world-and that what is good is 'everything that heightens the feeling of power in man, the will to power, power itself' ( $A$ $\$ 2$ ), we should expect to find in his writings exactly what I claim to find there: a picture of life and reality as will to power that appears to offer a descriptive account of them, but which he gives us adequate warning to recognize as a construction of reality from the viewpoint of his values" $(1990,126)$.

(3') BGE 22: "Nietzsche shows us how to generate a power-cosmology by 'interpreting' a text provided by science-physics in that case-in terms of his preferred aristocratic values" (2000, 130).

As far as I know, Clark is the first scholar to argue that Nietzsche endorsed the philosophical tendencies described above and that he illustrated this endorsement with his own philosophical theories, including especially his theory of reality as will to power. ${ }^{6}$ Nevertheless, in the time since she first presented her case, this proposal has come to be widely accepted by the Anglophone community of Nietzsche scholars. ${ }^{7}$ It is perhaps only a slight exaggeration to say that we need to remind ourselves today that Clark's proposal is an interpretation of Nietzsche's text and not just the text itself. We need to remind ourselves, that is, that Nietzsche doesn't actually ever say that he is endorsing these tendencies or that he is illustrating this endorsement with his own theory of reality as will to power. Of course, I agree with Clark that Nietzsche "doesn't write like other philosophers" and that "[h] e wants us to do a lot of the work ourselves-he doesn't just tell us what he wants to lead us to see" (Clark 2000, 123). So in what follows I want to

\footnotetext{
${ }^{6}$ Other philosophical theories of reality advanced by Nietzsche include, for example, radical flux, the necessary interconnection of all things, the unity of opposites, and the eternal recurrence of the same. Clark has offered similar, though much briefer, metaphilosophical reconstructions of each of these other theories, for example, of radical flux (Clark 1990, 206-207); of the unity of opposites (Clark and Drudrick 2012, 45-47); and of eternal recurrence (Clark 1990, 264-265).

${ }^{7}$ Even those scholars who have criticized Clark's interpretation of Nietzsche's doctrine of will to power do not dispute her reading and application of Nietzsche's metaphilosophical lessons in the opening sections of BGE. See, for example, Anderson (1996, 333-336; 2005, 90-91), Schacht (2000, 90), Richardson (2000, 109), Reginster (2006, 282 n. 2), Janaway (2007, 161-163), and Leiter (2013, 592-594). For an exception, see Owen (2000, 97), who raises good questions about Clark's reading (which she leaves unanswered in her response) in connection with the philosophical tendency to moralize nature.
} 
examine her most direct textual evidence in the opening sections of BGE outlined above for thinking that this is indeed what Nietzsche wanted to lead us to see. ${ }^{8}$

My analysis of Clark's primary textual evidence will have five parts. Against her reading, I will argue that this evidence shows instead that:

(I) Nietzsche only says that most past philosophers have in fact projected their values into all of reality, not that all philosophers have always done this or that he, or future philosophers following his lead, must also do this.

(II) Nietzsche does not endorse the philosophical idealization of the world as an exercise of intellectual will to power that is always salutary, but rather criticizes it as a merely provisional and limited attempt to gain intellectual power in the world as it actually is.

(III) Nietzsche does not just criticize past philosophers for dishonestly and self-deceptively pretending that their value-projections are accurate descriptions of reality, but also for dishonestly and self-deceptively projecting their values in the first place.

(IV) Nietzsche does not exclude philosophical value-projections from the realm of cognitions, but rather criticizes them as misjudgments resulting from the kind of cognitive error that Aristotle called the composition fallacy.

(V) Nietzsche does not admit that his own theory of cosmological will to power is an interpretation of reality in terms of his own preferred values, but rather criticizes all such value-projecting interpretations as flawed hermeneutics.

Following this analysis of Clark's primary textual evidence, I will argue further that, far from encouraging future philosophers to project their values into the world, Nietzsche actually proposes a new interpretive methodology of systematically subtracting all such previous value-projections. This new methodology is specifically designed to counter the misguided tendencies described in the metaphilosophical lessons offered at the start of BGE. Indeed, Nietzsche employs this new methodology to derive his own theory of reality as will to power-a theory which he thinks is able to avoid the cognitive errors and falsifications that have plagued the theories of past philosophers. This new methodology, he argues, will enable him, and future philosophers following his lead, to enhance their intellectual power in ways that were unavailable to past philosophers who deceived themselves about the nature of reality and their place in it.

\section{Philosophy past and future}

One of the principal themes in BGE is Nietzsche's attempt to draw a sharp line between, on the one hand, philosophy as it has typically been practiced in the past and, on the other, philosophy as he practices it and as he hopes it will be practiced in the future. This theme is announced straightaway in the subtitle of the book: "Prelude to A Philosophy of the

\footnotetext{
${ }^{8}$ Clark also presents some indirect arguments about the way in which Nietzsche deliberately constructs bad arguments for his theory of will to power in places like BGE 13 and BGE 36. See Loeb 2015 for my criticism of her reading of BGE 36. In that essay, I argue that Nietzsche's related image of showing us the world as will to power in his mirror (KSA 11:38[12]) does not mean that he has constructed a self-reflecting picture of the world, but only that he is offering a counterfactual thought-experiment whereby we can imaginatively project into the world our experience of the power struggle among our drives in order to explain and comprehend the truth of cosmological will to power that he has established through his new methodology. In this unpublished note, Nietzsche urges us to notice that we are like the world as a whole, not that the world as a whole is like us.
} 
Future." Although there is some debate whether Nietzsche means by this a future philosophy or a philosophy about the future, there are plenty of passages showing that he means at least the former-passages in which he announces, anticipates, and calls forth a new species of philosophers and a new kind of philosophy (cf. BGE 2, 42-44, 203). So when we read the title of Part One, "On the Prejudices of Philosophers," it is natural to think that Nietzsche has in mind only the prejudices of past philosophers, not his own prejudices or the prejudices of future philosophers he is calling forth.

But Clark thinks this is a mistake. She thinks that Nietzsche is also self-reflectively and honestly pointing out his own prejudices as well as the role they have played in inspiring his own philosophical theories. This is why she writes, for example, that Nietzsche warns us that his theory of cosmological will to power "is 'a desire of the heart that has been filtered and made abstract,' a 'prejudice' he has baptized 'truth"' (1990, 219). According to Clark, when Nietzsche writes about the philosophers' "prejudices" [Vorurtheile], he has in mind their ethical values and ideals:

The "prejudices, which they baptize truths" are precisely their values. Given the mention of "desires of the heart," these "prejudices" do not seem to be merely cognitive values ... Especially when we read BGE 5 in light of BGE 6's and 9's insistence that a philosophy always expresses the morality of the philosopher, it becomes clear that Nietzsche has something more like ethical values in mind here (Clark and Dudrick 2012, 66-67; cf. also 156). ${ }^{9}$

And this means, she argues, that, contrary to the usual and natural reading, Nietzsche is not using the term "prejudice" in a pejorative sense:

[T] he title of this first part of the book, "On the Prejudices of Philosophers," refers not to something problematic that philosophers must overcome but to the values (or prejudgments) that are essential to all philosophy. ... [O]n the assumption that Nietzsche is not objecting to all philosophy, it follows that he cannot be trying to show that what he calls "prejudices" are bad and must be overcome in the best philosophy. Some value or prejudgment will be essential to any philosophy. However, this does not prevent Nietzsche from leveling criticisms against the particular prejudice or valuation expressed in metaphysical philosophy (Clark and Dudrick 2012, 42; cf. also 32, 47, 156) ${ }^{10}$

As we have seen, then, Clark claims that there are only two differences Nietzsche finds between himself and past philosophers. First, they projected the wrong kinds of prejudices into the world, for example, the ascetic values embodied in Plato's forms or in the Stoics'

${ }^{9}$ Cf. also Clark 1983, 464, 466; Clark 1990, 208, 219, 221-222; Clark 2019, §6.

${ }^{10}$ Clark attempts to isolate BGE 2 as the only place besides BGE 5 from which we should derive what Nietzsche means when he writes about the prejudices of the philosophers. And because Nietzsche here associates the typical prejudice of metaphysicians with the kind of valuation that stands in the background of all their logical procedures, she infers that he is identifying prejudice with valuation (Clark and Dudrick 2012, 41-42). But in fact, as Nietzsche goes on to say, all he means is that this particular valuation is a prejudice because it is a merely foreground valuation, a merely provisional perspective, one that is perhaps adopted from within a nook or from a frog-like position below (see also BGE 44). Thus, Nietzsche is using the term "prejudice" in BGE 2 just as he uses it elsewhere in BGE and also in his other works, as concerning a very restricted, and therefore blinding, biased and distorting perspective (see Note 15 below). In his view, there are many kinds of prejudices that are not values (for example, the grammatical seductions mentioned in BGE P and BGE 20), and values only become prejudices when they have their origins in such restricted perspectives. I argue below that Nietzsche thinks his own valuation of will to power does not have such an origin and is therefore not a prejudice. 
rational laws $(2012$, 114). And, second, they were simply not aware of the prejudices subconsciously embodied in their philosophical theories and this self-deception led them to hide these prejudices from their readers as well. Commenting on the first difference, she writes that Nietzsche "wants the philosophy of the future to preserve this [valuecreating and value-legislating] function of traditional philosophy" but not in the way in which previous philosophers have gone about this task by reading ascetic and life-negating values into the world $(2019, \$ 6$ ). And commenting on the second difference, she writes, "this certainly means that there is going to be a fundamental similarity between Nietzsche's philosophy of the future and the old philosophy he rejects": 11

Nietzsche wants philosophers to be true to what he believes has always been the underlying impulses of philosophy: to create the world in the image of its own values. But he also calls upon philosophers to develop the truthfulness necessary for, among other things, recognizing what they are doing. (Clark 2000, 126)

Let me turn now to the textual details of BGE 5. It is true that this section uses universal language to describe philosophers: alle, allesamt, and sämmtlich. But Clark cannot cite this universal language as support for her claim that Nietzsche is including himself or future philosophers. This is because all of this language concerns the philosophers' dishonesty and she argues, rightly I think, that Nietzsche doesn't want to apply this charge to himself or to future philosophers following his lead. Instead, then, the most natural and charitable way to interpret Nietzsche's universal language in BGE 5 is to see it as restricted just to past philosophers. This reading is confirmed by Nietzsche's use of the present perfect tense in the first sentence of the next section: "Gradually it has become clear to me what every great philosophy up to now has been [Allmählich hat sich mir herausgestellt, was jede grosse Philosophie bisher war]: namely, the personal confession of its author and a kind of unintended and unwitting mémoires" (BGE 6, my italics in the first clause). ${ }^{12}$ Here Nietzsche sets up a deliberate contrast, on the one hand, between philosophy as it has been practiced so far by the likes of Kant and Spinoza and, on the other, philosophy as he is now practicing it or as he hopes it will be practiced in the future by the new species of philosophers he sees emerging. This sentence, with its reference to the past and its mention of personal confession [Selbstbekenntnis], also contains a direct allusion back to his obviously critical remark in the BGE Preface: ${ }^{13}$

$[\mathrm{P}]$ erhaps the time is very near when it will be understood again and again what has actually sufficed to serve as the cornerstone of such sublime and unconditional philosophical edifices as the dogmatists have constructed up to now [bisher], - [...] an audacious generalization of very narrow, very personal [sehr persönlichen], very human-all-too-human facts.

\footnotetext{
${ }^{11}$ Cf. also Meyer 2014, 244.

12 Here and throughout the rest of this essay, and with minor emendations, I have followed Adrian Del Caro's translation of BGE and GM, in Friedrich Nietzsche, Beyond Good and Evil / On the Genealogy of Morality, in The Complete Works of Friedrich Nietzsche, eds. Alan D. Schrift and Duncan Large, Volume 8 (Stanford University Press, 2014). The earlier draft of this sentence (KSA 14, p. 348; CWFN 8, p. 359) does not use the present perfect tense or the term "bisher," which indicates that these changes were made by Nietzsche in order to make his claim more precise.

${ }_{13}$ Nietzsche's criticism of philosophical childishness [Kinderei] and tyronism [Anfängerie] in this prefatory remark also anticipates his criticism in BGE 5 of the philosophers' innocence, that is, how easily they make mistakes and go astray, their childishness [Kinderei] and childlikeness [Kindlichkeit].
} 
Nietzsche's clear implication, then, is that his own philosophy is not a personal confession and has not been constructed in this generalizing fashion. ${ }^{14}$ Also, and more importantly, that philosophy, when practiced properly in the future, should avoid being reducible to some kind of personal confession. Previous canonical philosophers have simply been unaware of their subconscious compulsion to construct theories of the universe by generalizing their own very narrow, very personal, very human-all-too-human facts. Clark's interpretation of Nietzsche's term "prejudice" is therefore mistaken because he actually has in mind the highly problematic situation, which should be overcome, in which the philosophers' immersion in their own very narrow, very personal, very human-all-toohuman facts obscures and distorts their vision when they attempt to gain a view of the world outside of themselves. ${ }^{15}$ What they see is only themselves and their projections rather than the independent reality. This is why Nietzsche describes their philosophies as confessions and as memoirs that are unintended [ungewollter] and unwitting [unvermerkter]. But he, and the new species of philosophers that he sees emerging, will be aware of this compulsion and will avoid being influenced by it. Contrary to Clark, then, Nietzsche's point here is not that his self-awareness will allow him honestly to warn his readers that he is subject to this compulsion just like all previous philosophers. Instead, his point is that this self-awareness, and his understanding of misguided past philosophers, will lead him to resist this compulsion and work against it.

In her book-long commentary on Part One of BGE, co-authored with David Dudrick, Clark briefly considers and rejects this alternative reading of these particular passages (2012, 64-68, 146-156). ${ }^{16}$ Her argument against it depends partly on her interpretation of

\footnotetext{
${ }^{14}$ There are a few places where Clark claims that Nietzsche aims to illustrate this prefatory remark with his own theory of will to power and with the reasoning he offers in support of this theory. In particular, she claims: (1) he intends us to notice that this theory "is an 'audacious generalization' to the whole universe of the will to power, which Nietzsche originally understands as one human drive among others" (Clark 2009 \$6); and (2) he deliberately offers bad arguments for this theory in order to show "how little [he] would need in order to formulate arguments for a power-ontology or -biology that are comparable to the ones he thinks have traditionally furnished the cornerstones for philosophical systems." He thereby provides "a test of whether the time he hopes for is yet at hand, i.e., whether philosophers are yet willing and to recognize and face up to what has been going on in their philosophical system-building [namely, constructing visions of reality in the image of their own values]" (2000, 125-126; see also Clark and Dudrick 2012, 229 n.14; and Clark 2009 \$6). I argue against (1) below and against (2) in Loeb 2015.

15 This reading better fits his identification of the term "prejudice" with cognitive error in places like D116 and D149 and his more general use of the term in places that concern class, race, and gender prejudice (cf. D186, BGE 199, GS 348, GS 363). It also fits better with Nietzsche's other uses of the term in the rest of BGE-as meaning something problematic that should be overcome. In BGE 19 he says that philosophers are in the habit of adopting popular prejudices and exaggerating them, thereby aligning his idea of philosophical prejudices with his prefatory mentions of old popular superstitions and grammatical seductions which he says derive from peoples' commonalities (cf. also GS 354). Speaking of the power of moral prejudices in BGE 23, he says that it penetrates into even those places that would seem most devoid of presuppositions and operates in a damaging, inhibiting, blinding, and distorting fashion. In BGE 32 he says that the morality of intentions is a prejudice that must be overcome; in BGE 34 he asserts that the prejudice that the truth is worth more than mere appearance is the most poorly proven assumption in the world; in BGE 44, he characterizes prejudice as needing to be gotten rid of because it is stupid, it is a misunderstanding, and it banishes thinkers to a nook (see also BGE 2); and in BGE 22, he writes that the strong type of human being will benefit from the absence of prejudice in his training.

${ }^{16}$ Here, and in the rest of this paper, I will foreground Clark's authorship of this commentary (as she herself does when citing this book in Clark 2018), but I will of course have in mind both Clark and Dudrick when I refer to the interpretations offered in their co-authored book.
} 
what Nietzsche goes on to say in the rest of BGE 6 about the moral intentions of philosophers: ${ }^{17}$

BGE 6 opens with the claim that a (great) philosophy is "the personal confession of its author and a kind of involuntary memoir," and what it "confesses" to is evidently the philosopher's "moral (or immoral) intentions," the morality at which his philosophy aims. And the passage ends, as we have discussed, with the claim that his morality "bears decided witness to who he is." (Clark and Dudrick 2012, 151).

On this reading, it would seem obvious that Nietzsche is claiming that every great philosophy, including his own, is the personal confession and unintended memoir of the philosopher who authors it. ${ }^{18}$ This is something most scholars today agree about. ${ }^{19}$ Notice, however, that Clark has stripped away Nietzsche's reference to the past in the opening sentence of BGE 6 and thereby changed his first point so that it refers to the personal confession of every great philosophy, not just of every great philosophy up to now. ${ }^{20}$ Since Nietzsche's second point is part of the same opening sentence, she has also changed this point so that it refers to the moral (or immoral) intentions in every great philosophy, not just in every great philosophy $u p$ to now. ${ }^{21}$ And since Nietzsche's next sentence follows directly from his opening sentence, she has changed his third point so that it refers to the morality at which every great philosophy aims, not just that of every great philosophy up to now. ${ }^{22}$ Finally, when Nietzsche writes at the end of BGE 6 that, by contrast with scientific people, there is absolutely nothing impersonal in philosophers and that the philosophers' morality bears decided witness to who they are, she links these three points together so that Nietzsche's fourth point is changed to mean that every great philosophy bears witness

\footnotetext{
${ }^{17}$ For a similar argument, cf. Leiter 2018, 189-191, 195-196; and Meyer 2014, 243-244. Like Clark, they both reinforce this argument by citing Nietzsche's claim in BGE 211 that genuine philosophers are creators and legislators of values. Their implied reasoning seems to be that this creation and legislation requires that the values be legitimized by projecting them into nature. But this doesn't follow (especially since the attempted legitimization is supposed to be a transparent fraud) and Nietzsche himself never says that it does. It is true that Nietzsche mentions philosophical will to power in both BGE 9 and BGE 211, but it doesn't follow from this that he thinks the value-creation he praises in BGE 211 entails the value-projection he criticizes in BGE 9. In addition, I argue below that BGE 9 does not identify philosophical will to power with valueprojection. See also Loeb 2019 for my interpretation of BGE 211.

18 The claim that Nietzsche intended BGE 6 to describe his own philosophy is first proposed by Lou Salomé at the start of her 1894 study of Nietzsche's thought (Salomé 2001, 4). As supporting evidence she cites the September 16, 1882 letter (KSB 6, 259) in which Nietzsche praised her idea of "reducing philosophical systems to the personal records of their originators" as similar to his own idea when he taught the history of ancient philosophy in Basel (Salomé 2001, 3). But this letter, and Nietzsche's teaching in Basel (about "refuted and dead" philosophical systems), do not necessarily describe what he means in his later BGE 6 passage, or if they do, they refer once again to his account of past philosophers and not of his own philosophy or of the kind of philosophy he hopes will be practiced in the future.

${ }^{19}$ Cf. Lampert 2001, 30; Acampora and Ansell-Pearson 2011, 37, 46; Meyer 2014, 244. Against this consensus, there is the fact that at the end of his career Nietzsche intentionally wrote a memoir that mentions and summarizes, but does not develop or use, the philosophy he formulates in his previous works. In addition, the fact that Nietzsche uses a personal style to communicate his philosophy (EH "Books" 4), or that he relates the personal contexts in which he discovered his philosophy (GS P), or that he asserts personal ownership of his philosophy (BGE 23, 36, 43), does not mean that his philosophy is a personal confession or unwitting memoir in the precise sense articulated by him in BGE 5-6.

${ }^{20}$ Cf. also Clark and Dudrick 2012, 65; Clark 1990, 176.

${ }^{21}$ Cf. also Clark and Dudrick 2012, 42, 65-67, 147, 152; and Clark and Dudrick 2014, 365; Clark and Dudrick 2014 a, 343. Cf. also Lampert 2001, 31.
}

${ }^{22}$ Cf. also Clark and Dudrick 2014a, 343; Clark 2019, \$6; and Leiter 2018, 189-191, indeed, the title of his essay: “The History of Philosophy Reveals that 'Great' Philosophy is Disguised Moral Advocacy: A Nietzschean Case against the Socratic Canon in Philosophy” (2018, 185). 
to who the philosopher is, not just the morality that is the goal of every great philosophy $u p$ to now.

But let's suppose instead that we keep in mind Nietzsche's reference to the past throughout his discussion in BGE 6. And let's suppose we also keep in mind his implied contrast between, on the one hand, philosophy as misguidedly practiced by past philosophers like Kant and Spinoza, and, on the other, philosophy as he is now correctly practicing it or as he hopes it will be correctly practiced in the future. In that case, and following up on his critique in BGE 5, Nietzsche's actual metaphilosophical lesson in these two sections is that every great philosophy in the past has made the mistake of having moral (or immoral) intentions and of aiming at a morality. ${ }^{23}$ And since the philosophers' morality reveals who they are (cf. also BGE 187), he is arguing that every great philosophy in the past is inadequate because it is reducible to the author's personal confession and unintended memoir. Hence his recommendation of a new methodology that will ensure that new and superior philosophical theories, such as his own theory of cosmological will to power, will avoid having any moral (or immoral) intentions, will avoid aiming at any morality, and will thereby avoid being reducible to personal confessions and unintended memoirs.

Against this reading of BGE 6 it might be objected that Nietzsche must be speaking of all philosophers and not just past philosophers because he contrasts the types of the philosopher and the scientific scholar (Clark and Dudrick 2012, 153-154). The drive for knowledge, he writes, is not the father of philosophy, but instead all the different basic human drives have merely used knowledge (and misjudgment) as a tool. They have all attempted to philosophize in order to present themselves as the ultimate purpose of existence and as the rightful master of all other drives. For this reason, the philosophers' views, even their most far-fetched metaphysical claims, characterize them and there is absolutely nothing impersonal in them. By contrast, the real interests of scientific scholars lie elsewhere (for example, in family, politics, or earning money) and they might really have something like a disinterested drive for knowledge, a little clockwork mechanism, that works independently of all their other drives.

I agree that Nietzsche would certainly want to distinguish himself, as well as his idealized future philosophers, from scientific scholars. In fact, he does just this in BGE 211 when he distinguishers genuine philosophers who want knowledge for the sake of power from philosophical laborers who want knowledge for its own sake. ${ }^{24}$ In BGE 229-231 Nietzsche claims that past and future philosophers are both inspired to philosophize by their will to power, not by a drive for knowledge. But whereas past philosophers were led to construct false personified and anthropomorphic theories of the universe that helped them survive, he and future philosophers are no longer constrained by the same evolutionary pressures and are led to see the universe as it really is in order to acquire still greater power. Thus, in BGE 5-6 Nietzsche is explaining a crucial turning point in the development of the philosopher type, not suggesting that all philosophers are bound to project themselves and their values into the world as a whole. When he says that there is nothing impersonal in

\footnotetext{
${ }^{23}$ The mere fact that Nietzsche writes about past philosophies as "great" (grosse) does not show that he thinks of them uncritically or that he thinks that his own philosophy, which is presumably also great, is subject to the same criticism as they are.

${ }^{24}$ See also KSA 11:26[407]; 11:38[13]).
} 
(genuine) philosophers, this means that they don't disinterestedly seek knowledge for its own sake, not that they can't help but project their own very personal, very human-all-toohuman facts into the world as a whole.

Notice finally that, contrary to Clark's reading, Nietzsche does not ever say in these remarks from BGE 5-6 that the problem with previous philosophers is that they were being guided in their theorizing by the wrong kinds of prejudices or by the wrong kinds of moral intentions. Instead, his crucial parenthetical insertion of "immoral" intentions, along with his own sympathetic mentions of immoralism (BGE 23, 228), points to his unrestricted and unqualified view that it is a mistake for philosophers to be guided in their theorizing by any kind of prejudices or value-preferences. In particular, he warns us against thinking that his own interpretation of nature as will to power is guided by any moral or immoral intentions. After concluding BGE 36 with his thesis of cosmological will to power, he writes: "What? Does this not mean, using a popular expression: God is refuted but the devil is not - ?" On the contrary! On the contrary, my friends!" (BGE 37). And later in BGE, when deploying his thesis of biological will to power in a political context, he writes: "[Every healthy aristocracy] will have to be the incarnate will to power, it will grow, spread out, pull things in, try to gain the upper hand, - not due to some morality or immorality, but because it lives, and because life simply is will to power" (BGE 259, my emphasis added).

\section{Philosophy as the most intellectual will to power}

It seems to me that Clark's interpretive argument, as I have just reviewed it, finds stronger support in BGE 9 than it does in BGE 5-6. This is because here Nietzsche concludes his critique of the Stoics with remarks about philosophy and philosophers that do seem completely general:

But this is an old, eternal story: what happened back then with the Stoics still happens today just as soon as a philosophy begins to believe in itself. It always creates the world in its own image, it cannot do otherwise; philosophy is this tyrannical drive itself, the most intellectual will to power, to "world creation," to the causa prima.

Here, then, Nietzsche speaks of an old, eternal story about philosophy that still happens today, not just in the past-thus seeming to imply that it is happening even with his own philosophy. Indeed, Nietzsche seems to add, philosophers cannot avoid creating the world in their own image because this is the nature of philosophy-thus seeming to imply that he himself cannot avoid doing this. So it is not surprising that Clark feels entitled to apply this specific passage to Nietzsche's own theory of nature as will to power:

Nietzsche's point is that though philosophers claim otherwise, their theories are not even designed to arrive at truth. They are attempts to construct the world, or an image of the world, in terms of the philosopher's values. ... In the passage [BGE 9] I have just quoted, Nietzsche claims that this is true of all philosophy. If he is consistent about this, he must admit that his cosmological doctrine of the will to power is an attempt to read his values into the world and that he does not consider it to be true. His acceptance of it is inspired not by a will to truth, but by a will to construct the world in the image of his own values. The Stoics construct 
the world by picturing nature as subject to law, Nietzsche pictures the same nature as will to power. (Clark 1990, 221)

This certainly seems like a reasonable interpretation and application of this important passage. However, the sticking point in Nietzsche's concluding remarks is his qualification that what happened back then with the Stoics still happens today "just as soon as a philosophy begins to believe in itself" [sobald nur eine Philosophie anfängt, an sich selbst zu glauben]. What does Nietzsche mean by this? Here Nietzsche is not saying, as Clark infers, that what happened back then with the Stoics must still happen today with all philosophy, but only that this will still happen today just as soon as a philosophy begins to believe in itself. ${ }^{25}$ Now, according to Clark, we have good reason to think that "Nietzsche's philosophy believes in itself" (Clark 1983, 463) or that "Nietzsche has a philosophy in which he believes" (Clark 2000, 126), so we are entitled to find his implication that this happens with his philosophy too. ${ }^{26}$ But this gloss is problematic, given her claim above that Nietzsche doesn't actually believe in the truth of his theory of nature as will to power (cf. Clark 1990, 220, 227, 240). Clark might want to argue further that what Nietzsche means is that he believes in the valuation of will to power that is covertly expressed by his theory. But this seems like a lot to read into Nietzsche's simple phrase. Also, since she argues that according to Nietzsche previous philosophers actually did believe in the literal truth of their philosophies, she would have to claim that the sense in which he thinks they believed in their philosophies is completely different than the sense in which he believes in his own philosophy. And then she would no longer have a straightforward sense in which Nietzsche is illustrating his metaphilosophical lesson with his own philosophy.

In fact, the most natural reading of Nietzsche's phrase is that a philosophy believes in itself in the sense that it takes special pride in itself. This reading is supported by his use of the related phrase "das Glaube an sich selbst," in the later BGE 260. For here Nietzsche describes noble morality as including a belief in oneself, a pride in oneself, [der Glaube an sich selbst, der Stolz auf sich selbst]. This association is supported by Nietzsche's description in BGE 9 of the Stoics as having a pride [Stoly] that wants to prescribe and incorporate their morality and their ideal into nature itself. This pride, he adds, subconsciously leads them to demand that nature be nature according to the Stoa and to want to make all of existence conform only to their own image-as a colossal eternal glorification [Verherrlichung] of Stoicism. ${ }^{27}$ However, Nietzsche's point now seems to be much more critical than Clark allows. And this impression is confirmed when he extends this same point about the Stoic pride into the obviously critical claim that some kind of abysmal arrogance [irgend ein abgründlicher Hochmuth] finally implants in them the insane hope [die Tollhäusler-Hoffnung] that because they know how to tyrannize themselves it must be the case that nature too lets itself be tyrannized.

\footnotetext{
25 In her 2010 essay, "Nietzsche as Anti-metaphysician," included in her collection of essays, Clark simply omits this qualification, thus showing that she doesn't think it is significant: "Because he claims that all philosophy does what the Stoics did, Nietzsche can't criticize metaphysicians for reading their values into the world (unless he is willing to dispense with all philosophy, which he is not)" (Clark 2015, 257, my italics).

${ }^{26}$ Cf. also Lampert 2001, 36.

${ }^{27}$ Here Nietzsche also alludes back to his assertion in BGE 6 that every single one of the basic human drives aims to rule all the other drives and attempts to philosophize in this vein, wanting to present just itself as the ultimate purpose of existence. Since this assertion is obviously critical, we should infer that Nietzsche is also being critical of this same desire in BGE 9. The human drives and the Stoics are making the same mistake when they philosophize in this way.
} 
The question, then, is whether Nietzsche would say that his own philosophy believes in itself, is proud of itself, in the specific sense attributed to the Stoics. Clark's answer to this question is obviously yes: "He [Nietzsche] wants nature to live only after his own image, as an eternal generalization and glorification of what he finds valuable" (Clark 1990, 124). Indeed, in her most recent discussion, she argues that the effect of Nietzsche's argument in the later BGE 36:

is an 'audacious generalization' to the whole universe of the will to power, which Nietzsche originally understands as one human drive among others. In generalizing this drive, Nietzsche can be seen as generalizing and glorifying what he values, just as he claims philosophers have always done and must do (Clark 2019, §11).

However, this answer seems undermined by Nietzsche's critical remark in BGE 9 that this generalization and glorification is the result of an insane hope implanted in the Stoics by their abysmal arrogance. It seems very unlikely that Nietzsche would want to describe his own philosophy in these same pejorative terms. Clark's answer also seems to conflict quite directly with Nietzsche's prefatory criticism of the traditional practice of building a sublime philosophical edifice upon the cornerstone of some audacious generalization [Verallgemeinerung] of very narrow, very personal, very human, all-too-human facts (BGE P). Surely Nietzsche has this prefatory criticism in mind when he says that the Stoics demand that nature conform to the Stoa and that all of existence exist only in their own image - as a colossal generalization [V erallgemeinerung] of Stoicism. ${ }^{28}$ So it is fair to ask in response to Clark's answer whether Nietzsche's qualification is not supposed to indicate precisely the opposite- that a philosophy like his does not fashion some colossal selfglorifying image, is not abysmally arrogant, and is not inspired by some insane hope that all of nature is just like him and his values. Instead, his point seems to be that the philosophy of the future should avoid these misguided tendencies as much as possible.

Clark might want to remind us at this point that Nietzsche concludes BGE 9 with the following sentence: "It always creates the world in its own image, it cannot do otherwise; philosophy is this tyrannical drive itself, the most intellectual will to power, to the 'creation of the world,' to the causa prima." [Sie schafft immer die Welt nach ihrem Bilde, sie kann nicht anders; Philosophie ist dieser tyrannische Trieb selbst, der geistigste Wille zur Macht, zur „Schaffung der Welt“, zur causa prima. ${ }^{29}$ Isn’t Nietzsche saying here that all philosophy always creates the world in its own image and cannot do otherwise? Indeed, that philosophy just is the tyrannical drive to create the world in its own image? This is how Clark reads this sentence when she writes that "Nietzsche tells us [in BGE 9] that philosophy itself is the most 'spiritual will to power'-precisely because it reads its values into the world" $(2000,126) .{ }^{30}$ Or, when she explains in her most recent discussion that

\footnotetext{
${ }^{28}$ Clark suggests that Nietzsche is asking us to apply this prefatory criticism to his own cosmological theory of will to power in order "to illustrate the view of philosophy presented earlier in the same book" and to show us how he, just like previous philosophers, presents his interpretation of the world as true and argues for it on the basis of amazingly little (Clark 2019, \$11). The problem with this idea, as I explain below, is that Nietzsche assumes his own true theory of the nature as power ("Indifferenz selbst als Macht") as the background for his criticism that the Stoic theory of nature is a false generalization.

${ }^{29}$ Although all the mainstream translators of BGE have chosen to render "geistigste" as "spiritual," the context clearly suggests that Nietzsche has in mind the more precise and concrete idea of a philosopher's intellectual activity.

${ }^{30}$ Cf. also Acampora and Ansell Pearson 2011, 62.
} 
according to BGE 9 philosophers cannot avoid generalizing and glorifying what they value (2019, \$11).

My response to this reminder is that we need to read this concluding line more carefully. What Nietzsche actually writes in the first clause, referring back to the last sentence, is that as soon as a philosophy begins to believes in itself it always creates the world in its own image and cannot do otherwise. After the semicolon, he introduces a new idea, that philosophy in general is this tyrannical drive itself, the most intellectual will to power, to the "creation of the world," to the causa prima. ${ }^{31} \mathrm{He}$ doesn't say that philosophy in general is the tyrannical drive to create the world in its own image. ${ }^{32}$ But when paired together with an abysmally arrogant philosophy that glorifies itself, this tyrannical drive to create the world then becomes a tyrannical drive to create a self-reflecting picture of the world. Thus, Nietzsche does indeed endorse the philosophers' intellectual will to power that tyrannically drives them to create theories about the whole world, even in cases like the Stoics. But he criticizes the self-glorifying and self-projecting tendencies that lead them to create false pictures of the world - tendencies which Clark thinks he exemplifies and encourages in future philosophers. This is why he insists, against the Stoics: "For all your love of truth you force yourselves so long, so persistently, so hypnotically and rigidly to see nature falsely, namely Stoically, that you're no longer able to see it in any other way ..."

One of Clark's reasons for thinking that Nietzsche exemplifies this tendency in his own philosophy is that we know he values will to power and it can't be a coincidence that he also conceives of nature as will to power. But what if he derives his valuation of will to power from his theory that the world is will to power? Against this idea, Clark argues that, just like the Stoics and all previous philosophers, Nietzsche's own solution to the problem of how to derive an "ought" from an "is" is to first hide the "ought" in the "is" and then to pretend that he has merely found it there. Like the Stoics and all previous philosophers, he presents a picture of reality that is really a construction of reality from the viewpoint of his own values as if it were a descriptive account of reality that he merely discovered, and from which, miracle of miracles, he is able to derive support for the very values he favors. ${ }^{33}$ The only difference, Clark says, is that Nietzsche knows he is doing this and uses his metaphilosophical lessons to warn us about this deception.

${ }^{31}$ Clark reads the pronoun "Sie" in the clause "Sie schafft immer die Welt nach ihrem Bilde, sie kann nicht anders" as referring forward to the term "Philosophie" after the semi-colon, thereby inferring that Nietzsche thinks philosophy in general always creates the world in its own image and cannot do otherwise. But actually "Sie" refers backward to "eine Philosophie" in the last sentence, meaning that this is something that is done by a philosophy as soon as it begins to believe in itself.

32 It might appear (cf. Clark 2012, 147; Clark 2019 \$ 11) that Zarathustra is saying this in his speech on self-overcoming (Z II $\$ 12$ ) when he claims that the will to truth of those who are the wisest is actually a will to power. What he means by this, he says, is that those who are the wisest want to make all of existence bend and submit to their intellect. Precisely because they doubt, with proper suspicion, whether existence is even intellectually conceivable, they want to make it such-that is, they want to create a world in the image of their own intellect that is smooth and subject to their intellect and that is its mirror and reflection. But Nietzsche's interjection about the philosophers' doubt and proper suspicion shows that he is criticizing this philosophical tendency, not encouraging it. See also GS 373 where Nietzsche insists that existence is not subject to the human intellect. Thus, when Zarathustra speaks of those who are wisest he is contrasting his own greater wisdom with theirs, implying that his own will to truth and greater will to power does not want to make all of existence bend and submit to his intellect. As the title of the proximate section suggests ("On the Famously Wise"), Nietzsche is here referring to wisdom as it has been defined up to now, not wisdom as he defines it on behalf of a new kind of philosophy in the future.

${ }^{33}$ Clark 2000, 126; cf. also Clark 1983, 466 and 1990, 223-224. 
But, again, what if Nietzsche believes that he is completely different from the Stoics and all previous philosophers because, given his new method for doing philosophy (as the subtraction of previous value-projections), he really bas discovered what reality is like and then derived his values from this discovery? ${ }^{34}$ I don't think that Clark can simply reject this possibility without begging the question in regard to her interpretive claim that Nietzsche intends to include his own philosophy in the concluding remarks of BGE 9. Clark herself cites textual evidence from BGE 186 and BGE 259 that supports this possibility (Clark 1990, 223-224). Since there is no expressivist language in either of these passages, she would have to make the rather implausible argument that Nietzsche intended to illustrate his introductory metaphilosophical lessons with them as well.

Perhaps Clark's implied point above is that there is no way to argue from "is" to "ought" without committing the naturalistic fallacy. Therefore, Nietzsche had to hide his valuation of will to power within his theory of cosmological will to power. But John Richardson $(2013,775)$ has offered what seems to me a convincing response against this line of reasoning. For suppose that Nietzsche's theory of cosmological will to power entails his naturalistic account of human beings as living organisms who strive for power and value power (BGE 36; GM II:12). What Nietzsche aims to show, then, is not that we ought to value power because the world, and thus life, is will to power, but rather that we including Nietzsche) simply do value power because the world, and thus life, is will to power. So actually Nietzsche is just deriving facts from facts, and he himself reminds us that there is no "objective" reason to value power outside of our perspective as living organisms (TI "The Problem of Socrates" 2; "Morality as Anti-Nature" 5). If this interpretation is persuasive, it helps to show that Nietzsche does not believe that his own philosophy is creating the world in his own image or in the image of his own values. More importantly, it helps to show that the actual metaphilosophical lesson of BGE 9 is that future philosophers should avoid doing just this. ${ }^{35}$

One last question Clark might want to ask in connection with her argument above is why Nietzsche, who clearly values the will to power, would want future philosophers to resist intellectual will to power at all-even when it tyrannically drives self-glorifying philosophers to create self-reflecting pictures of the world. Since Nietzsche calls into question the value of truth from the very start of BGE, it shouldn't really matter that he thinks these pictures are false. Indeed, just a few sections before BGE 9, he writes that, for him, the falsehood of a judgement is not yet an objection to a judgment and that the question is to what extent the judgment is life-promoting (BGE 4). Hence he cannot be objecting to the falsehood of the Stoic picture because he values truth unconditionally and for its own sake. Moreover, since he says that the Stoics' self-reflecting picture of the world helps them to increase their feeling of intellectual power, and since he claims that life is will to power (BGE 13), it is clear that he thinks that this picture is indeed life-promoting for them. So why does he emphasize the falsehood of the Stoic self-reflecting picture of the world and imply that there is something objectionable about this falsehood?

\footnotetext{
${ }^{34}$ Compare Clark's assessment: "But if Nietzsche's ontological doctrine is the result of reading his values into the world, his claim that the world is will to power can have no legitimate role in arguments for his values or against other values. Nor can the doctrine that all human behavior aims at power, if that is merely a specification of the ontological doctrine. Yet it is clear that Nietzsche uses the will to power in such arguments and gives no sign of regarding them as illegitimate" (1983, 466).

${ }^{35}$ Clark considers this natural alternative reading in Clark and Dudrick 2012, 65-68.
} 
As I will discuss at more length below, Clark would answer this question by saying that Nietzsche is here only objecting to the fact that the Stoics dishonestly pretend, even to themselves, that they are driven only by their love of truth. Thus, commenting on Nietzsche's claim that the Stoics have forced themselves to see nature "falsely," she explains (quite implausibly) that what he means by this is that the Stoics "may appear - and may take themselves - to seek only truth, but in fact they are actually driven by a deeper will to construct reality as a reflection of their values." 36 But this answer doesn't explain why Nietzsche objects to the falsehood of the Stoic value-projection even though it is lifepromoting. Nor does it help to explain why Nietzsche thinks, as I have argued, that future philosophers should resist intellectual will to power when it drives philosophers to demand that all of existence conform only to their own image. However, suppose we take seriously Nietzsche's careful formulation in BGE 4 about the question being, not whether a judgment is life-promoting, but rather to what extent a judgment is life-promoting (wie weit es lebenfördernd). In that case, Nietzsche might be objecting to the falsehood of the Stoic picture simply because it is not life-promoting enough — not enough, that is, compared to his own more accurate picture of reality or to the more accurate pictures of those future philosophers who will follow his lead. On this reading, the reason that he and future philosophers should resist intellectual will to power when it drives previous philosophers like the Stoics to falsify the world is that they see an opportunity for a far greater discharge of their own intellectual will to power through their own more accurate theories.

Although Nietzsche doesn't explain these additional points in BGE 9, I think he is concerned to draw them out when he returns to discuss the same themes in his later important sections, BGE 229-230. For in these sections he outlines in a lot more detail the process whereby previous philosophers like the Stoics were able to discharge their intellectual will to power by creating the world in their own image. ${ }^{37}$ Translated back into nature, he explains, their needs and capacities were the same as those physiologists posit for everything that lives, grows and multiplies. What they needed, he writes, was to be masters in and around themselves and to feel like masters; their ultimate goal was the feeling of growth, the feeling of increased power. Nietzsche then outlines four different kinds of related capacities that helped them achieve this goal: 1) appropriating the foreign by assimilating the new to the old; 2) overlooking or repulsing what cannot be so assimilated, that is, whatever is utterly contradictory in the "external world"; 3) allowing self-deception regarding the kind of falsification that has been performed by the first two capacities; and 4) and readiness to deceive others about this falsification as a means of selfconcealment and self-defense. There are many details in Nietzsche's descriptions of these capacities that apply to what he has said in his BGE opening passages about previous philosophers who have constructed the world in their own image. For example, 1) concerns a will to simplicity and to retouching and falsifying the whole to suit itself; 2) involves a kind of state of defense against much that is knowable, a decision in favor of ignorance; 3) includes an enjoyment in the arbitrary narrowness and secrecy of some nook, in the all too near, in the foreground, in what is magnified; and 4) includes an enjoyment of the feeling of security behind clever masks. All of these features help to explain what

\footnotetext{
${ }^{36}$ Clark and Dudrick 2012, 68; cf. also 142-143). See also Clark and Dudrick 2014a, 342-343.

${ }^{37}$ Here I disagree with the Clark's far-fetched interpretive argument (Clark and Dudrick 2012, 141-147) that in BGE 9 Nietzsche does not ascribe will to power to the Stoics but only to their subpersonal drives.
} 
Nietzsche means when he discusses the prejudices of philosophers. In terms of Clark's focus on the Stoics' projection of their preferred values, Nietzsche's point here is that these philosophers deceived themselves and others into believing that any aspects of the universe which were not lawlike and self-tyrannical had be either assimilated to these Stoic values or simply ignored.

Having thus outlined the motivations and strategies behind the self-reflecting theories of previous philosophers, Nietzsche then turns to explain how these can all be countered by "that sublime inclination of the knowledge-seeker who insists on profundity, multiplicity, and thoroughness, with a will which is a kind of cruelty of the intellectual conscience and taste" (BGE 231). Alluding back to the language of BGE 5 and BGE 9, he writes that "the knowledge-seeker forces his intellect to know, against the inclination of the intellect and often enough even against the wishes of his heart-by way of saying No where he would like to say Yes, love, and adore" (BGE 229). ${ }^{38}$ Instead of constructing philosophical theories about the world as they would like it to be according to the wishes of their hearts, knowledge-seekers like himself cruelly force their intellects to see the world as it really is. And instead of projecting themselves and their preferred values into the world so that they might glorify themselves and these values, knowledge-seekers like himself cruelly force their intellects to say No where they would like to say, Yes, love, and adore. Thus, whereas previous philosophers like the Stoics indulged "the fundamental will of the intellect which unceasingly strives for the apparent and superficial," knowledge-seekers like himself insist on profundity and thoroughness as a means of hurting and violating this same fundamental will within themselves. They turn this will against itself as a means of increasing their feeling of power far more than they could ever do by fashioning their own self-reflecting theories of the universe.

There is a lot more that needs to be said here, especially with reference to Nietzsche's further development of these ideas in the second essay of his next book (GM II:16-18). For example, there is good reason to think that Nietzsche believes that the ever-increasing escalation of internalized intellectual will to power within future philosophers will eventually lead to some kind of explosive re-direction outward. ${ }^{39}$ In that event, future philosophers will no longer have to content themselves with a mostly illusory appropriation of that which is foreign, which means that their feeling of increased power will be far greater than it was before. ${ }^{40}$ In any case, I think that this further elaboration is sufficient to show that Nietzsche certainly did object to the falsification involved in the value-projections of previous philosophers like the Stoics. Also, that the source of his

\footnotetext{
${ }^{38} \mathrm{Or}$, as Nietzsche puts it in his previous book, to say No to their ultimate hope and intoxication, to their creation of a world before which they could kneel (Z II: "On Self-Overcoming").

${ }^{39}$ See Loeb 2010, 233, 240. Nietzsche also writes in his unpublished notes about the consequence of humans seeing through the previous falsifications of nature and recognizing it as will to power. When they translate themselves back into this redeemed nature, there will be an increase in the feeling of power among the most powerful humans, thereby enhancing the human species as a whole (cf. KSA 12: 5[71]).

40 Although he has not yet officially formulated his own theory of will to power to replace Darwin's theory of natural selection, Nietzsche offers the same kind of argument in GS 110, just after he has criticized the fundamental error of anthropomorphic value-projection in GS 109: "Thus, knowledge became a piece of life itself and, as life, a continually growing power: until finally knowledge and those primeval fundamental errors collided with each other: both as life, both as power, both in the same human being. The thinker: that is now that being in whom the drive for truth and those lifepreserving errors fight their first fight, after even the drive for truth has proven itself as a life-preserving power. Compared to the significance of this fight, everything else is a matter of indifference ..."
} 
objection, and also of his wanting to resist, or rather turn against itself, the intellectual will to power that compels such value-projecting falsifications, is actually his valuation of this same will to power. Although these falsifications certainly enhanced the intellectual will to power of previous philosophers, Nietzsche thinks that his criticism of these falsifications, leading him to a more accurate knowledge of reality, can enhance his own intellectual will to power to a far greater degree. ${ }^{41}$

\section{Philosophical dishonesty and self-deception}

According to Clark's interpretation, Nietzsche's metaphilosophical lessons in the opening sections of BGE are concerned to distinguish two separate stages of philosophical theorizing. In the first stage, philosophers project their values into all of reality and construct a picture of the world that reflects these values. In the second stage, they claim that this construction is an accurate description of the world which they have discovered through rational investigation. Clark then emphasizes Nietzsche's explicit criticism, especially in BGE 5, of the dishonesty and self-deception involved in the second stage. But because BGE 5 does not appear to offer this same criticism of the first stage, and because BGE 9 seems to approve of the first stage, she infers that Nietzsche does not think that this first stage is dishonest or self-deceptive and, indeed, does not object to it at all: "What Nietzsche objects to in previous philosophers is not that they read their values into the world, but that they pretended to be doing something else, that they were not 'honest enough in their work' (BG 5)" (Clark 1990, 240). Hence, she argues, Nietzsche advises future philosophers to continue reading their values into the world but to stop pretending, even to themselves, that their resulting picture is an accurate description of the world. In Clark's view, Nietzsche illustrates this metaphilosophical lesson by reading into the world his own valuation of power while at the same time honestly letting us know that this is precisely what he is doing. Citing the language of BGE 5, Clark writes that "Nietzsche seeks to display the courage and self-knowledge to warn us that his [cosmological] doctrine [of the will to power] is 'a desire of the heart that has been filtered and made abstract,' a 'prejudice' he has baptized 'truth' (1990, 219). Notice Clark's point here about Nietzsche baptizing his prejudice as the truth. According to her interpretation, Nietzsche continues the traditional practice of disguising his value-projection as the truth, but he makes sure that this disguise is not effective by warning us that this is what he is doing. ${ }^{42}$ In this way, he alerts us to the dishonesty and self-deception of other philosophers who claim they are discovering the truth.

I agree with Clark that Nietzsche is especially interested in criticizing the dishonesty and self-deception involved in the traditional practice of philosophical theorizing described above. But I disagree with her claim that Nietzsche locates this dishonesty and selfdeception only in the second stage outlined above. Instead, I think he is arguing that both

\footnotetext{
${ }^{41}$ I think this conclusion serves to undermine the central thesis, offered in Clark's interpretation of Part One of BGE, about the magnificent tension of the spirit "between the will to truth, the will to represent reality in terms of what is actually there, and the will to value, the will to represent reality in a way that supports one's values (other than truth)" (Clark 2015, 18). See Riccardi 2012 and Katsafanas 2014 for alternative critiques of this thesis.

${ }^{42}$ Of course, the question then arises, not addressed by Clark, as to why anyone who has understood this warning should believe in Nietzsche's value-projection. And if no one does, how can it fulfill what Clark says is its intended value-legislating and life-affirming function? Also, since Clark thinks that Nietzsche continues to disguise his value-projection as the truth, and since disguising is a form of dishonesty, she is claiming, rather paradoxically, that Nietzsche can be trusted because he is honest about his dishonesty.
} 
stages belong to a single dishonest and self-deceptive stratagem. In abstract terms, Nietzsche's point is that the reason previous philosophers have subconsciously projected their preferred values into all of reality is so that they can then claim the validity of these values by pretending to have discovered them there. As we have seen, Clark herself accepts this reading of a single and unified self-deceptive stratagem when she writes as follows:

What has been going on [in their philosophical system-building], the opening sections of Beyond Good and Evil go on to explain, is that philosophers have been constructing visions of reality in the image of their own values. Of course, instead of having the courage to admit this to themselves or to "warn an enemy or friend," they have pretended to be doing something quite different, namely, discovering the truth about reality. Nietzsche thus suggests that the typical philosopher's "solution" to the problem of how to derive an "ought" from an "is" is to first hide the "ought" in the "is" (BGE 9), and then to pretend that one has merely found it there. His claim is that philosophers have presented pictures of reality that are really constructions of reality from the viewpoint of their own values as if they were descriptive accounts of reality that they have merely discovered, and from which, miracle of miracles, they are able to derive support for the very values they favor. (Clark 2000, 126). ${ }^{43}$

I completely agree with this well-crafted explanation of Nietzsche's metaphilosophical lessons, although I am puzzled as to why Clark doesn't notice the tension with her explanations elsewhere. As she rightly observes here, Nietzsche's point is that typical philosophers subconsciously hide their preferred values in reality so that they can then pretend to find them there and thus claim support for them in reality. Her term "hide" certainly indicates a kind of dishonesty and there is no reason to think of this dishonesty as separate or different from the kind of dishonesty and self-deception she associates with her next term "pretend." Hiding these values and then pretending not to have hidden them are simply two aspects of the same single effort to (self-)deceive. And since Clark's term "hide" is just another way for her to say "project," she is admitting that Nietzsche thinks there is dishonesty and self-deception involved in the typical philosophical practice of value-projection.

The important question Clark does not ask in this explanation is why Nietzsche thinks that typical philosophers feel the need to take such elaborate (self-)deceptive measures in order to claim support for their preferred values. The answer, he suggests in BGE 5, has to do with the very personal and even arbitrary nature of the philosophers' preference for their values. This preference, he says, is akin to an assumption [vorweggenommener Satz], a notion [Einfall, an "inspiration" [Eingebung], a heartfelt wish [Herzenswunsch], and a prejudice, bias, or preconception [Vorurtheil]. This last term is especially important because Nietzsche entitles Part One of BGE, "On the Prejudices of Philosophers" [von den Vorurtheilen der

\footnotetext{
${ }^{43}$ In her most recent discussion, Clark puts the same point this way: "Gradually it has become clear to him, he says, that philosophers' values are the 'real germ' from which their systems grow. While pretending to be concerned only to discover truth, philosophers have actually been wily advocates for prejudices (values) they call 'truths'. They interpret the world in terms of their own values, and then claim that their interpretation, which they present as objective knowledge, gives everyone reason to accept these values - as the Stoics justified their ideal of self-governance on the grounds that nature itself obeys laws, an interpretation they arrived at by projecting their ideal of self-governance onto nature (Beyond Good and Evil \$\$1-9 [Werke VI.2: 207-216])" (Clark 2019, §6). This reading of BGE 9 matches mine below, except that she crucially omits to mention that the self-deceived Stoics projected their ideal on nature in order to justify it on these grounds.
} 
Philosophen]. For him, as we have seen, this term means the limited and biased perspective of the philosophers' personal preferences - that is, of their very narrow, very personal, very human-all-too human facts (BGE P). He says that they want to conceal this bias and to avoid being seen as advocates and spokesmen for their personal prejudices. By subconsciously projecting these prejudices into all of reality, they pretend to themselves and others that these are not merely their own personal preferences. And by then subconsciously pretending that these projections are accurate descriptions of this reality, they avail themselves of a fictitious ontological and epistemic support for these merely personal preferences. ${ }^{44}$

This unified reading of Nietzsche's views on philosophical dishonesty and self-deception finds strong support in BGE 9 and 22. In the first of these sections, Nietzsche focuses on the Stoic's preferred value of self-tyranny. His description shows that he thinks this is a very idiosyncratic value that instills in them a personal prejudice and bias. Next, he shows how the Stoics practice the first stage of philosophical theorizing by subconsciously prescribing and incorporating this morality and ideal into nature. They claim that, because they are good at tyrannizing themselves, and because the Stoic is a piece of nature, therefore nature too allows itself to be tyrannized. They demand that nature be nature "according to the Stoa" and they want to make all of existence conform only to their own image - as a colossal eternal glorification and generalization of Stoicism, that is, of selftyranny. It is clear that Nietzsche thinks that this first stage of value-projection involves dishonesty and self-deception because he exclaims in disbelief, "into nature, even nature" [der Natur, sogar der Natur] and because he says that this first stage is inspired by an abysmal arrogance and an insane hope. After that, Nietzsche explains how the Stoics practice the second stage of philosophical theorizing by gleefully pretending to read the canon of their law out of nature. Here his suggestion of dishonesty and self-deception is conveyed by his claim that the Stoics pretend [vorgebt] to do this and by his associated description of them as strange actors and self-deceivers [wünderlichen Schauspieler und Selbst-Betrüger]. In this way, after the deployment of the single unified stratagem consisting of these two (self)deceptive stages, the Stoics are now in a position to declare that their own personal and idiosyncratic value-preference is validated by nature: they say that they want to live according to nature and they proclaim as their chief ethical principle the imperative "live according to nature." Here is how Nietzsche puts this circular reasoning in his first draft of BGE 9: "Actually, you first form nature in the image of your wise man! And then you would like to form yourselves in the image of your image!" (KSA 14, 349). But at this point Nietzsche introduces the language of truth and falsehood in order to undermine the Stoics' concluding validation of their personal valuation of self-tyranny. Since the Stoics have now declared that their projection of this prejudice into nature is actually a true description of the world, he is able to refute them as follows: "For all your love of truth you force

\footnotetext{
${ }^{44}$ In his comments on Clark's interpretation, Richardson argues that she reads Nietzsche "as basing his values-above all his value of 'affirming life'-in nothing more than his own preference for it, which he hopes to induce us to share" (2000, 115). Clark responds that she disagrees strongly with this reading because she would "include among the bases of Nietzsche's values his deep and sustained analyses of human history and human psychology.” (2000, 134). However, the problem with this response is that the Stoics would argue that they too have included among the bases of their values a deep and sustained analysis of human history and human psychology. So it is the projection of these values, and not the basis of these values, that Nietzsche singles out as problematic — quite simply, because human values, history, and psychology are located where they do not belong. By contrast with the Stoics who project their values into nature in order to validate them, Nietzsche derives his values from the view of nature he discovers by subtracting all such previous projections.
} 
yourselves so long, so persistently, so hypnotically and rigidly to see nature falsely, namely Stoically, that you're no longer able to see it in any other way ..." In this way, he returns to his introductory assertion of the fraudulent and deceptive nature [Betrïgerei der Worte] of the Stoics' claim to want to live "according to nature." Nietzsche's point here is one that he intends as a general metaphilosophical lesson, namely, that the Stoics' practice of the (self-)deceptive stratagem consisting of these two stages of philosophical theorizing leads them to construct a falsifying picture of the world. They see nature falsely, namely Stoically, because the Stoic law, morality and ideal that they claim to find in nature don't actually exist there at all. 45

Although BGE 22 is not about philosophers, Clark thinks this section offers important support for her reading because it discusses similar theorizing practices involving the projection of law into nature (Clark 1990, 222). So I want to show that a similar counterreading can be offered here too. In this case, the theorizers are modern physicists and their preferred value is the democratic belief in equality before the law. Accordingly, the first stage in their theorizing is to project this preferred value into nature by claiming the "conformity of nature to law," exclaiming "long live natural law!" and asserting: "Everywhere equality before the law — nature is no different and no better off than we are in this regard." Nietzsche is clearly commenting on the dishonesty and self-deception of this first stage when he writes that this is a nice example of ulterior motives, disguising once again the physicists' plebeian hostility against everything privileged and aristocratic. Next, the physicists deploy the second stage of their theorizing when they pretend that their theory of nature's conformity to law is a fact and that they are merely reading the canon of their law out of the "text" of nature. ${ }^{46}$ Nietzsche comments on the dishonesty and self-deception involved in this second stage when he writes that this supposed conformity exists only thanks to their bad interpretive methods [schlechte Interpretation-Künste]. And he exposes their pretense when he writes that the physicists' conception of natural law [Naturgesetzt] is actually an interpretation of the text of nature, not the text itself. But he also observes that these two stages, taken together as parts of a single unified stratagem, are intended to yield a theory of nature that will validate the physicists' preferred value. This theory, he says, is only a naively humanitarian justification [eine naiv-bumanitäre Zurechtmachung] with which they want to appease and accommodate the democratic instincts of the modern soul. And then he undermines this attempted justification by declaring the theory to be bad "philology" [schlechten 'Philologie'] and a distortion of meaning [Sinnverdrehung]. Again, Nietzsche's point here is one that he intends as a general metaphilosophical lesson, namely, that the modern physicists' practice of the single (self-) deceptive stratagem consisting of these two stages of philosophical theorizing leads them to distort the meaning of the "text" of nature. They offer a democratic distortion of this

\footnotetext{
${ }^{45}$ Despite her non-cognitivist interpretation of philosophical value-projection, Clark seems to concede this point when she writes: “This will to value, we have seen, aims to create or construct the world in accordance with the philosopher's values. Nietzsche clearly believes that this drive has led previous philosophers astray, into illusion. What they claimed to find in the world - for example, Plato's forms, rational laws, necessary connections - appeared to be there only as a projection of their way of looking at the world and, ultimately, of their values. So they found only an image of themselves in the world rather than what was really there" (Clark and Dudrick 2012, 114).

${ }^{46}$ In Clark's reading of BGE 22, Nietzsche is using the term "text" [Text] to refer to the physicists' discovery of regularities in nature, upon which they impose an "interpretation" of law-like conformity (Clark 1983, 465-466; Clark 1990, 222-223; Clark 2000, 124-125, 130; Clark 2012, 87-96, 224). I disagree with this reading because I think Nietzsche would say that the physicists' discovery of regularities is already an imposed interpretation, even without the additional claim of law-like conformity. But this disagreement doesn't make a difference to my argument above.
} 
meaning because the democratic ideal of equality that they claim to find in nature doesn't actually obtain there at all.

In sum, the primary textual evidence that Clark cites to support her interpretation shows that Nietzsche's metaphilosophical lessons about philosophical dishonesty and selfdeception are not quite what she claims. Yes, he is concerned to point out the dishonesty and self-deception involved when philosophers claim that their value-projections are accurate descriptions of reality. But he also thinks that these value-projections are themselves dishonest and self-deceiving and he sees both the value-projections and the pretense that they are something else as part of the same single (self-)deceptive stratagem. From this it follows that Nietzsche is not just recommending that future philosophers stop disguising their value-projections, but also that they stop projecting their values in the first place. Indeed, if they simply discontinue the first-stage strategy of making these valueprojections, there will be no need for them to deploy the second stage of disguising them. In a recommendation that is not at all an endorsement, he chastises previous philosophers for not having the courage to honestly admit, even to themselves, that their theories of the world were merely attempts to validate their own personal and idiosyncratic prejudices. Which means, of course, that Nietzsche is not letting us know that his own theories of the world are merely disguised projections of his preferred values-not because he is being dishonest, but because he believes that this is not actually the case. Indeed, rather the reverse, he is letting us know that his own theories, such as the cosmological will to power, are carefully conceived so as to avoid being inspired and biased by his own personal prejudices. Clark claims that Nietzsche is honestly and courageously warning us about his pretense to have offered his theory of will to power as a true description of reality. But his actual point is that, unlike previous philosophers, he is not engaging in any pretense at all that he needs to warn us about. When he claims that his theory of will to power is a true description of reality, this is because he believes it really is such, and not just because he is self-deceived. And when he urges future philosophers to be just as honest as he is, he doesn't mean that they should honestly warn us about their deceptions, he means that they should just stop deceiving us and themselves.

\section{Philosophical prejudices, errors, and falsifications}

One of the most puzzling aspects of Clark's interpretation is her claim that Nietzsche denies any cognitive status to philosophical theories that he thinks are attempts to construct an image of the world in terms of the philosophers' preferred values. Nietzsche's point, she writes, is that "though philosophers claim otherwise, their theories are not even designed to arrive at truth" and "do not belong to the realm of knowledge" (Clark 1990, 221, 223). After claiming that Nietzsche illustrates this metaphilosophical lesson with his own picture of nature as will to power, she says that he means to warn us that this picture "is not a cognition, not an accurate description of what is in nature, but a projection of its author's values onto a text provided by science" (Clark 2000,125). Similarly, commenting on BGE 22 and Nietzsche's comparison there of his own picture of nature with the picture of nature presented by modern physicists, Clark writes that he is concerned to point out the similarity between the two, namely, that "neither is a cognition; each is a projection of values onto the same text" $(2000,125)$. 
If Clark is right about this, we should not expect to see Nietzsche diagnosing cognitive problems that he finds in the value-projecting activity of previous philosophers. Yet, as we have seen, this is just what he does in those places where Clark finds her most important textual evidence. In BGE 5 and 9, he alludes back to his prefatory claim that these theories were audacious generalizations of very narrow, very personal facts; in BGE 5 , he says that these philosophers were sly spokesmen for their personal prejudices; in BGE 9, he says that the Stoics saw nature falsely when they saw it Stoically; and in BGE 22, he says that the modern physicists' picture of nature is a bad and distorting interpretation. So why does Clark think that Nietzsche denies the cognitive status of these theories? How does she make sense of these various places where he appears to presuppose this cognitive status in order to criticize it?

As far as I can tell, Clark's primary argument for making this strong assertion about Nietzsche's denial of cognitive status to value-projecting theories has to do with her distinction between the two stages of philosophical theorizing outlined above. According to Clark, the first stage of value-projection is not yet a cognition. And since the second stage of converting this value-projection into a cognitive description is merely a pretense, she infers that the resulting theory cannot be counted as a cognition. But is this a good argument? In terms of her first premise, I agree with her that Nietzsche thinks that the philosophers' projection of their preferred values into all of reality is an expression of will to power that is not designed to arrive at the truth. He makes this point very clearly about the Stoics in BGE 9. But he also says in BGE 6 that the previous philosophers' inspiring drives - in order to achieve legitimate mastery over all their other drives-used the philosophers' cognitions (and misjudgments!) [der Erkenntniss (und der Verkenntniss!)] as tools that would help them to portray themselves as the ultimate purpose of all existence. Hence, although previous philosophers such as the Stoics may not have conceived their theories so as arrive at the truth, it is still the case that they were using their cognitions and cognitive functions as tools that would help them to project their values into all of reality and to represent themselves as the ultimate purpose of all existence. So these cognitions can certainly be evaluated, and Nietzsche's exclamation mark after "der Verkenntniss" suggests that he thinks they were misjudgments-which fits his later claim in BGE 9 that the Stoics saw nature falsely when they saw it Stoically. ${ }^{47}$

As for Clark's second premise, we should question her background assumption that the cognitive disguise that philosophers impose on their value-projections shouldn't be counted as a cognition. She seems to be assuming, for example, that, because the description of lawlike nature offered by the Stoics and modern physicists is actually a disguised projection of their ideal law into nature, that this is therefore not really a description and that the question of its accuracy makes no sense. But this doesn't follow. What follows instead is precisely what Nietzsche himself says follows, namely, that this description is a false view of the world and a bad interpretation of the text of nature. Regardless of their actual sources and motivations, the Stoics and the modern physicists are certainly proposing a descriptive theory which can be evaluated as such. Even if the

\footnotetext{
${ }^{47}$ Clark seems to admit this point when she writes: "Nietzsche thus claims that, at least in the case of the great philosophies, knowledge, mistakes, and cognitive problems are always employed in the service of constructing the world (i.e., a picture of the world) so that it reflects the philosopher's values or ideal" (Clark 1990, 176).
} 
philosophers didn't conceive their theories in order to arrive at the truth, once they took the next step and claimed that these theories were true, even if only for the sake of (selfdeceptive) pretense, then we are entitled to evaluate them accordingly. And once we factor in our knowledge of their actual sources, motivations, and methods into this evaluationnamely, their preferred values, their motivating will to power, and their projection-then our logical conclusion should be that these are false descriptive theories of the world and distorting interpretations of nature. In terms of Clark's own helpful explanation, if the typical philosophers' "solution" to the problem of how to derive an "ought" from an "is" is to first hide the "ought" in the "is," and then to pretend (even to themselves) that they have merely found it there, there is certainly no reason for us to conclude that their claim to have found it there is not a cognition and cannot be evaluated for its accuracy. Instead, since we know that the "ought" is not actually in the "is," we should conclude that this is a false cognition.

Although Clark's primary argument fails, I think she has another argument for thinking that Nietzsche denies the cognitive status of value-projecting theories. This has to do with his claim in BGE 5 that previous philosophers who have advanced such theories have acted as if they had discovered and reached their real opinions through the selfdevelopment of a cold, pure, divinely unconcerned dialectic. In reality, however, they were (self-deceptively) defending, with reasons sought after the fact, some assumption, a notion, an "intuition," most often a desire of the heart that had been filtered and rendered abstract. What this means, Clark argues, is that these philosophers reached their theoretical conclusions simply on the basis of their assumed ethical values and without any kind of cognitive reasoning, argument, or evidence (Clark and Dudrick 2012, 67). It is true, she writes, that Nietzsche thinks these philosophers "pretend to come to their positions as a consequence of arguments" when in fact "their views really begin life as 'a desire of the heart that has been filtered and made abstract' (Clark and Dudrick 2012, 67). But since he says that these philosophers defended their theories with arguments they sought after the fact of conceiving them, she thinks he means that they did not have any reasons for their theories before the fact. 48

It seems to me, however, that Clark misinterprets this famous passage. Nietzsche doesn't say that previous philosophers pretended to discover and reach their theories through reasoning in general, but rather through the self-development of a cold, pure, divinely unconcerned dialectic (durch die Selbstentwicklung einer kalten, reinen, göttlich unbekümmerten Dialektik). What he has in mind here is that these philosopher like Spinoza and Kant aimed to conceal the extremely personal and prejudiced character of their inspiring desires by pretending (even to themselves) that they discovered their theories through impersonal and impartial reasoning. This point leaves it open for Nietzsche to think that these philosophers have in fact been guided to conceive their theories through some kind of dialectic that is not self-developed and that is not cold, pure, and divinely unconcernedthat is, through some kind of extremely personal and prejudiced reasoning. ${ }^{49}$ And, indeed, this is just the kind of reasoning that he emphasizes in the BGE preface when he comments on the kind of audacious generalization (Verallgemeinerung) of very narrow, very

${ }^{48}$ Cf. also Clark and Dudrick 2014, 364-365; and Leiter 2018, 189-191.

${ }^{49}$ Not self-development, because motivated by external prejudice; not cold, because inspired by the heat of passions; not pure, because corrupted by prejudices; and not divinely unconcerned because personally and humanly concerned. 
personal, very human-all-too-human facts that has sufficed to serve as the cornerstone of previous sublime and unconditional philosophical edifices. It is also, as we have just seen, the kind of reasoning he describes in BGE 6 when he comments on the way in which the inspiring drives of previous philosophers have manipulated cognitions and false cognitions in order to portray themselves as the ultimate purpose of existence. And it is the kind of reasoning that Nietzsche highlights in BGE 9 when he comments on the Stoics' desire to make all existence conform only to their own image, as a colossal glorification and generalization (Verallgemeinerung) of Stoicism. Finally, it is the kind of reasoning he mentions in BGE 22 as leading modern physicists to declare: "Everywhere equality before the law-nature is no different and no better off than we are in this regard."

In all these passages, then, Nietzsche is not saying, as Clark supposes, that previous philosophers have abstained from all reasoning when conceiving their theories. Instead, his point is that they have pretended to conduct impartial and unbiased reasoning in order to conceal even from themselves their actual use of inductive reasoning in their powermotivated quest to glorify and universalize themselves and their personal prejudices. Since this inductive reasoning is precisely what Clark calls "projection," this means that she is mistaken in supposing that Nietzsche denies the cognitive status of these value-projections or of the philosophical theories that result from these projections. Also, it means that she is mistaken in arguing that Nietzsche does not object to these value-projections, and the proof of this can be found in the very formulations he uses to express them. Thus, when he writes in the BGE preface that previous philosophers have self-deceptively built their theories of the universe on the basis of audacious generalizations of very narrow, very personal, very human-all-too-human facts, his point is that the infinitesimally small number and radically idiosyncratic character of these facts obviously undermines this inductive reasoning and fails to support these theories. And when he claims in BGE 6 that the philosophers' personal drives would like to use the philosophers' cognitions and misjudgments in order to portray themselves as the ultimate purpose of all existence, his exclamatory emphasis on misjudgments [der Erkenntniss (und der Verkenntniss!)] is an obvious criticism of this absurd ambition. Similarly, when Nietzsche explains in BGE 9 how the Stoics self-deceptively construct a colossal generalization of Stoicism, and how the Stoics infer that because the self-tyrannizing Stoics are a piece [Stück] of nature therefore all of nature lets itself be tyrannized, he is obviously criticizing the Stoic's grandiose inductive reasoning as outrageous and completely unwarranted. Finally, when he describes the modern democratic physicists' self-deceptive inference of equality before the law everywhere from the fact that they see themselves as equal before the law, his point is that this is a ridiculous and faulty inductive inference. The fallacy in all these cases is the same, and although Nietzsche doesn't name it, it corresponds to what Aristotle first labeled as the composition fallacy - namely, the kind of faulty inductive reasoning that attributes to a whole the properties that belong to a small and atypical part of the whole (Sophistical Refutations 165b-166b). In every one of these cases, the fallacious reasoning invariably leads to a falsified view and a distorted interpretation of the whole-namely, a view of the whole, and an interpretation of the whole, as having properties which belong only to an infinitesimally small and radically atypical subset of the whole. ${ }^{50}$

50 Since Nietzsche is an anti-realist about values (GS 301; Z II: "1001 Goals"), he denies the metaethical view that a human valuation of X becomes an ontological property of X. See Loeb 2021. 
If all of this is right, then it simply cannot be the case, as Clark writes, that Nietzsche wants future philosophers to create the world in the image of their own values (Clark 2000, 126). For this would mean wanting future philosophers to indulge their personal prejudices, present fallacious reasoning, and construct false theories. Nor can it be the case, as she supposes, that Nietzsche intends for us to interpret his own theory of will to power as an honestly acknowledged construction of reality from the viewpoint of his own values (Clark $1990,126)$. Let me turn now to show this last point in more detail.

\section{Nietzsche's own philosophical theory}

BGE 9 and 22 are two places in which Nietzsche mentions his own philosophical theory of cosmological will to power while at the same time discussing his metaphilosophical lessons. For this reason, they are among the most important pieces of textual evidence for evaluating Clark's thesis that Nietzsche intends for us to interpret his own philosophical theories as illustrations of these lessons. I will begin with BGE 9. In this section, Nietzsche begins his critique of the Stoics by asking them to think about nature along the lines of his own theory of nature as will to power:

You want to live "according to nature"? Oh you noble Stoics, what verbal trickery! Think of a being such as nature, wasteful without measure, indifferent without measure, without purpose and consideration, without mercy and justice, fertile and barren and uncertain at the same time, think of indifference itself as powerhow could you live according to this indifference? Living - is that not precisely wanting to be different than this nature? Is living not assessing, preferring, being unjust, being limited, wanting to be different?

Although Clark doesn't ever address this first half of the section, I think it creates problems for her interpretation. This is because Nietzsche is here positing his own philosophical theory of indifference as power [die Indifferenz selbst as Macht] as an accurate description of nature that undermines the Stoics' ethical imperative to live according to nature. It's true that Nietzsche merely asks the Stoics to think about what this theory says. But there is nothing in this passage to suggest that he does not believe in the truth of his theory or that he is proposing his theory as a projection of his own values. Indeed, the fact that he presents his own theory without any such suggestion and then describes the false Stoic theory of nature as involving just such a value-projection would seem to indicate that he believes his own theory of nature is different and better than the Stoic theory precisely because it does not involve such a falsifying value-projection. If this is right, there is no reason to think that Nietzsche wants us to interpret his own theory of will to power as an illustration of the metaphilosophical lesson which he exemplifies with the Stoic theory of nature. I think this is why Clark concentrates instead on BGE 22 as her best textual support and even as a means of shoring up her reading of BGE 9 (since both sections involve the idea of nature's conformity to law). So I will turn to this section next.

In BGE 22 Nietzsche presents his own theory of will to power as an alternative interpretation of the text of nature to the one offered by modern physicists:

But like I said, this [modern physicists' conception of natural law] is interpretation, not text; and someone could come along who, with the opposite intention and interpretive method, is able to infer instead a tyrannically ruthless 


\section{The Role of Values in Nietzsche's Metaphilosopby}

and relentless imposition of power claims from the same nature and with respect to the same phenomena - an interpreter who so convincingly opened your eyes to the "will to power" with its lack of exceptions and its unconditional nature, that nearly every word, and even the word "tyranny" itself, would ultimately appear useless or as weakening and mitigating metaphor — as too human ...

Now, in Clark's view what is most important about this presentation of his own theory is that Nietzsche follows it up with the following sentence: "Supposing this too is only interpretation — and you will be eager enough to make this objection? — well then, so much the better.- " According to Clark, this sentence "appears to come right out and say what I have been claiming about Nietzsche's 'doctrine': that it is not the truth about nature but is 'only interpretation"' (Clark 2000, 124). And what Nietzsche means by this, she argues, is the following:

When Nietzsche concedes that "this too"- this picture of nature as "will to power"- is "only interpretation," this can only mean that it is "interpretation" in the same sense in which nature's conformity to law is. Like the latter, it is a case of "bad philology": it is not a cognition, not an accurate description of what is in nature, but a projection of its author's values onto a text provided by science. There is a difference between the two projections, namely that Nietzsche identifies with the aristocratic values from the viewpoint of which nature appears as will to power, whereas he is fighting the dominance of the democratic values that yield nature's conformity to laws. But this difference should not distract us from the similarity: neither is a cognition; each is a projection of values onto the same text. (Clark 2000, 125)

In her earlier discussion, Clark includes the following gloss on Nietzsche's concluding words: "I therefore take his 'so much the better' as an admission that his doctrine of the will to power does read his values into nature, that he therefore does not regard it as any truer than the idea that nature conforms to law, but that this is fine with him since he thereby remains consistent with everything he has said about knowledge and philosophy" (Clark 1990, 223).

I agree with Clark that BGE 22 is a crucial piece of evidence for her metaphilosophical reconstruction of Nietzsche's philosophy, but I don't think that her reading of this section is as obvious as she claims. The key question is what Nietzsche means when he says that someone might come along, obviously suggesting himself, who has "the opposite intention and interpretive method" [mit der entgegengesetzten Absicht und Interpretationskunst]. ${ }^{51}$ Picking up on Nietzsche's point that modern physicists are projecting into nature their democratic and egalitarian values, and keeping in mind our background knowledge that Nietzsche's own values are directly opposed to these, Clark assumes that Nietzsche means that he is projecting into nature his own anti-democratic and inegalitarian values. So when he claims that instead of nature's conformity to law he would find instead the tyrannically relentless claims of power, she infers that this means he would "discover" in nature the will to power that he has already projected there. Since Nietzsche argues that the physicists' interpretation involves bad interpretative methods [schlechte Interpretations-Künste], bad

${ }^{51}$ Here I have translated Nietzsche’s terms "Kunst" and "Künste” in terms of the original sense of "können," as concerning an ability or a method. Thanks to David F. Tinsley for his advice on this point. 
“philology" [schlechte "Philologie'], and distorted meaning [Sinnverdrehung], it must be the case that he means that his own interpretation is likewise bad and distorted, except for the crucial caveat that at least he is being honest about this.

The problem with this reading of Nietzsche's phrase about the opposite intention and interpretive method is that he doesn't actually explain the "opposite" in terms of opposite values being projected. In fact, he doesn't say anything at all in this section about his own values, or about the values of someone who might come along with the opposite intention and interpretive method-much less about any projection of such values into nature. So all of this is pure conjecture on Clark's part. This leaves it open that Nietzsche's phrase means something completely different. Instead of saying that value-projection is still happening, just with opposite values, he might mean that the opposite of value-projection is happening, meaning the subtraction, withdrawal, or extraction of previously projected values. On this alternative reading, the modern physicists' interpretation involves bad philology, bad interpretive methods, and distorted meaning because it wrongly imports into the text of nature their idea of human egalitarian laws in such a way that the actual power relations in nature are obscured, constrained, diminished, or ignored. ${ }^{52}$ By contrast, Nietzsche's own interpretation involves good philology, good interpretive methods, and undistorted meaning because it subtracts this previously imported idea so as to reveal that all laws are absolutely lacking in nature. As a result, on his interpretation, all the actual tyrannicalseeming power relations in nature are now exposed and displayed before our eyes [vor Augen stellen]. Whereas the Stoics similarly claimed to read out of nature [aus der Natur zu lessen] the canon of their law, in reality they were only finding the canon that they had already incorporated into [einverleiben] nature. In fact, Nietzsche suggests, even the word "tyrannical" is a human metaphor that still wrongly imports human values into nature and therefore serves to weaken and mitigate the lack of exceptions and the unconditionality of the actual power relations in which every power draws its ultimate consequence in every moment. The modern physicists' interpretation therefore involves bad hermeneutics and distorted meaning because it projects human values into a sphere of reality where they don't actually exist. By contrast, Nietzsche's interpretation is superior because it subtracts these previously imported human values from a sphere of reality where they don't actually exist and shouldn't have been projected in the first place. But both of these are of course still only human interpretations of the text of nature, not the text itself. ${ }^{53}$ Also, contrary to Clark, both of these are cognitions. But Nietzsche's interpretation of nature as will to power is more true than the physicists' interpretation because it includes less projective error and hence less falsification of this text of nature. ${ }^{54}$

\footnotetext{
${ }^{52}$ See also GM II:12 where Nietzsche contrasts his own theory of a power-will playing itself out in all events with the modern democratic idiosyncrasy against everything that rules and wants to rule. The latter, he says, has been allowed to penetrate into the most rigorous and seemingly most objective sciences of physiology and biology - in such a way that the essence of life, its will to power, goes unheeded and is overlooked, denied, and conjured away. According to Clark, the set-up of this passage, especially Nietzsche's phrase "Ich wollte sagen," should remind us of BGE 22, except that here he is generating a power-biology, not a power-cosmology, by interpreting a text provided by science, this time biology, in terms of his preferred values (Clark 2000, 130).

53 This means that Nietzsche defines "interpretation" independently of value-projection, something rejected by Clark and Dudrick $(2012,224-229)$ on the basis of their reading of BGE 14. I don't have the space to discuss this reading. here. But notice that Clark's equation of interpretation with value-projection, along with her non-cognitivist understanding of valueprojection, means that she is not able to speak of true or false interpretations (which Nietzsche clearly does).

${ }^{54}$ See note 46 above.
} 


\section{Nietzsche's new interpretive methodology}

Let me now summarize the results of my critical analysis of the textual evidence in BGE 5-6, 9 and 22. I think Clark is right to suggest that Nietzsche is concerned in these passages with metaphilosophical lessons that have important consequences for how should we interpret his own theories such as the will to power. I also agree with her that the subject of these lessons is the philosophers' tendency to subconsciously project themselves and their values into all of reality. But whereas she claims that Nietzsche thinks this tendency is unavoidable and salutary as long as it is honestly acknowledged, I have argued that he thinks it is completely avoidable and should be resisted. This tendency should be resisted because it reduces philosophical theories to mere personal confessions and because it involves flawed reasoning that leads to falsifying theories of reality. The flawed reasoning attributes to the whole universe the value-oriented features of its infinitesimally small set of radically atypical human components, and the resulting theories are false because they claim that these features belong to the whole universe. For example, Nietzsche explains in BGE 9, the Stoics projected into all of nature their own ideal of self-tyranny. But this meant projecting the living organism's characteristic desire to be different into a whole of reality that is actually indifferent without measure. Similarly, he explains in BGE 22, modern physicists have projected their own moral preference for egalitarian laws into a whole of reality where laws are absolutely lacking and where even the word "tyranny" is an unsuitable metaphor because it is too human. Accordingly, against Clark's claim that Nietzsche's own theory of cosmological will to power is an honestly acknowledged projection of his own valuation of power into all of reality, I have argued that it is actually the result of his new interpretive methodology of detecting, criticizing and subtracting all such previous value projections in order to discover what the whole of reality is actually like.

In the BGE passages I have examined above, Nietzsche alludes to this new interpretive methodology and puts it to work when examining the theories of previous philosophers such as the Stoics. Nevertheless, it might be asked, if this methodology is as important as I say it is, why doesn't he formulate it more explicitly and programmatically? My reply is that he is counting on his readers to know that he had already done so in the crucial section 109 of his previous book, The Gay Science. Given its significance to my argument, I would like to quote this section in full here:

Let us beware! — Let us beware of thinking that the world is a living being. Where should it expand? On what should it feed? How could it grow and procreate? After all, we know roughly what the organic is: and are we then supposed to reinterpret what is inexpressibly derivative, late, rare, accidental, which we perceive only on the crust of the earth, as something essential, universal, eternal, as those people do who call the universe an organism? This disgusts me. Let us beware even of believing that the universe is a machine; it is certainly not constructed for a single purpose, the word 'machine' pays it far too high an honor. Let us beware of assuming in general and everywhere anything as elegant as the cyclical movements of our neighboring stars; even a glance at the Milky Way raises doubts whether there are not much coarser and more contradictory movements there, as well as stars with eternally linear paths, and so on. The astral order in which we live is an exception; this order and the considerable duration 
that is conditioned by it have again made possible the exception of exceptions: the development of the organic. The character of the world as a whole, by contrast, is for all eternity chaos, not in the sense of a lack of necessity but of a lack of order, organization, form, beauty, wisdom, and whatever else our aesthetic human qualities are called. Judged from the vantage point of our reason, the unsuccessful attempts are by far the rule, the exceptions are not the secret aim, and the whole musical mechanism repeats eternally its tune, which must never be called a melody, — and ultimately even the phrase 'unsuccessful attempt' is already an anthropomorphism bearing a reproach. But how could we reproach or praise the universe! Let us beware of attributing to it heartlessness and unreason or their opposites: it is neither perfect, nor beautiful, nor noble, nor does it want to become any of these things, in no way does it strive to imitate humans! In no way do our aesthetic and moral judgements apply to it! It also has no drive to selfpreservation and no drives at all; nor does it observe any laws. Let us beware of saying that there are laws in nature. There are only necessities: there is no one who commands, no one who obeys, no one who transgresses. Once you know that there are no purposes, you also know that there is no accident; for only against a world of purposes does the word 'accident' have a meaning. Let us beware of saying that death is opposed to life. The living is merely a species of what is dead, and a very rare species. - Let us beware of thinking that the world eternally creates new things. There are no eternally enduring substances; matter is as much of an error as the god of the Eleatics. But when will we be done with our caution and care! When will all these shadows of god no longer obscure our thinking? When will we have completely de-deified nature? When may we begin to naturalize us humans by means of the pure, newly discovered, newly redeemed nature? 55

As Paolo D'Iorio (2011, 61-89) has shown, Nietzsche's preparatory notes and contemporaneous book annotations reveal that he composed this section in direct response to contemporaneous cosmological debates among prominent philosophers and physicists such as Otto Caspari, Eugen Dühring, Eduard von Hartmann, William Thomson, Johannes Gustav Vogt, and Johann Karl Friedrich Zöllner. In this section, Nietzsche reviews their organicist, mechanistic, materialistic, and panpsychist cosmologies and he criticizes these theories for projecting anthropomorphic attributes and value judgments into the whole universe. The cognitive mistake in this kind of projection, he explains, is that attributes which belong to that which is merely a special case, to that which is inexpressibly rare, and to that which is the exception of exceptions have been reinterpreted as universal, as the rule, as belonging to the character of the world as a whole, and as existing in general and everywhere. Or, put in Aristotle's terms, all these theories have committed a composition fallacy that has led them to construct false theories of the cosmos. For example, Vogt claims that the world includes everywhere and for all eternity the elegant cyclical movements of our neighboring stars when in fact the astral order in which we live is an exception and even a glance at the Milky Way raises doubts whether there are not much coarser and more contradictory movements there, as well as stars with

55 With a few minor emendations, this is the translation in Friedrich Nietzsche, The Gay Science, ed. and trans. Walter Kaufmann (Vintage, 1974). 


\section{The Role of Values in Nietzsche's Metaphilosophy}

eternally linear paths, and so on. And Caspari claims that the world includes everywhere and for all eternity the kind of organic life that we perceive only on the crust of the earth, and that is a very late development, and that has been made possible, only derivatively and accidentally, by the considerable duration enabled by our own atypical astral order. ${ }^{56}$

At the end of GS 109, then, Nietzsche suggests a new interpretive methodology that will counter this kind of cognitive mistake and falsification of reality-namely, the dedeification of nature. Alluding to Plato's foundational allegory of the cave, the metaphor Nietzsche deploys here is that of dispelling the obscuring shadows of God (GS 108). Since he identifies these shadows as humans' projections of themselves and their values, it is clear that he has in mind the detection, criticism, and subtraction of all such projective errors. The result, he writes, will be a pure, newly discovered, and newly redeemed nature. By this he means that his new methodology will enable us to discover for the first time what the world as a whole is really like once it is no longer obscured by all our projected shadows of ourselves and our values. This striking ending to GS 109 is important as a transition into the very next section, GS 110, because it suggests that this methodology is precisely the means whereby future thinkers will finally be able to liberate humans from the inherited species-preserving cognitive errors that have been incorporated in them since time immemorial. This methodology, Nietzsche suggests, will enable these thinkers to champion the opposing quest for truth and knowledge that they have only recently incorporated within themselves as a new kind of life-preserving power. ${ }^{57}$

I think this famous manifesto is as clear evidence as one could want against Clark's interpretive claim that Nietzsche "wants philosophers to be true to what he believes has always been the underlying impulses of philosophy: to create the world in the image of its own values" (Clark 2000, 126). So it is surprising that she doesn't mention GS 109 in any of her discussions. ${ }^{58}$ The reason for this omission, I think, is that she views this section as belonging to the period in Nietzsche's development when he still believed to some extent in the idea of the "true world" or "thing-in-itself" (Clark 1990, 95-125). It makes sense, then, that in the one place where she briefly considers the new interpretive methodology I've outlined above, Clark argues (against Richard Schacht) that it would mean committing Nietzsche to believing in the existence of the thing-itself:

[According to Schacht] if we are to avoid misinterpreting [the world's actual nature], we must pull out again what we have merely projected into it (206), what depends on our perspective. ... I believe that this answer presupposes the very model of knowledge Nietzsche uses perspectivism to combat. It presupposes the existence of a thing-in-itself whose nature is distorted by the subjective factors that influence its appearance from the various perspectives on it. (Clark 1990, 153-154; cf. also 206-207).

\footnotetext{
${ }^{56}$ In a preparatory note, Nietzsche writes of Caspari's idea of "das All als Organismus": "Dies ist immer noch Vermenschung der Natur!” (KSA 9: 11[201]).

57 This transition is reinforced by Nietzsche's mention in both sections of the Eleatics and the projective error of enduring substances.

58 This is all the more surprising given her acknowledgement of Nietzsche's opposition to anthropomorphic conceptions of nature (Clark, 2019, \$11) and her mention of the projection of anthropomorphic concerns in BGE 22 (Clark 2000, 125).
} 
It seems to me, however, that this response is inadequate because it simply accepts Schacht's conflation of the terms "what depends on our perspective" and "what we have merely projected into the world." Given this conflation, it would have to be the case that Nietzsche's methodological idea, proposed in GS 109 and reiterated in BGE 9 and 22, of subtracting the previously projected human idea of egalitarian laws from our conception of nature somehow commits him to the existence of the "thing-in-itself." Or that, for example, if we stop thinking of nature as a living organism, or as rational, or as beautiful, we are somehow committed to the idea of "the way the world is in itself, that is, apart from, or independently of, any of its interpretations" $(1990,154)$. But this doesn't follow. On Nietzsche's view, it is perfectly consistent to believe in both the inescapability of perspectival truth and the falsifying nature of anthropomorphic value-projections. In GS 109, Nietzsche explicitly says that our aesthetic and moral judgments do not apply in general and everywhere, or to the total character of the world, or to what is essential, universal, and eternal in the world. ${ }^{59}$ But none of these universalist terms are intended as Kantian descriptions of the world as it really is in itself, that is, apart from all human perspectives or interpretations of it. For Nietzsche, the truth-seeking project of viewing the world as it is apart from our anthropomorphic value-projections-what he calls a completely de-deified nature, or the pure, newly discovered, newly redeemed nature-is in no way the same thing as the self-contradictory idea of viewing the world as it is apart from any human perspectives or interpretations. ${ }^{60}$

Given her emphasis on Nietzsche's intellectual development, Clark could object at this point that Nietzsche changed his mind from the time of writing GS to the time of writing BGE and that he abandoned the new interpretive methodology announced in GS 109. But in her first book she actually lines up the first edition of GS and BGE as belonging to the same stage of intellectual development (Clark 1990, 95-125). We can also find strong evidence of methodological continuity between these two texts when we compare GS 109 with Clark's own textual evidence from BGE. Most importantly, Nietzsche repeats the methodological point of GS 109 when he claims in BGE 9 that the Stoics have mistakenly inferred that because the Stoic is a piece of nature therefore all of nature must be just like the Stoics. Also, Nietzsche writes in GS 109 that there are no purposes [Zwecke] in nature, a point he reiterates in BGE 9 when he asks the Stoics to think about a being such as nature that has no aims or intentions [Absichten und Rücksichten]. And he also writes in GS 109 that nature does not observe any laws and that we should avoid saying that there are any laws in nature. As we have seen, this is a point he repeats and emphasizes in BGE 22 when he writes that laws are absolutely lacking in nature and that modern physicists are proposing a bad interpretation when they claim that nature conforms to law.

\section{Conclusion}

If all of this is right, it should be the case that Nietzsche regards his own philosophical theory of cosmological will to power, as first proposed in BGE 9, 22, and 36, to be a result

\footnotetext{
${ }^{59}$ In his preparatory note, Nietzsche writes: "Wir müssen es uns gänzlich unvernünftig-mechanisch vorstellen, dass es mit gar keinem Prädikat von ästhetischem und moralischem Werthe getroffen warden kann” (KSA 14, 254).

${ }^{60}$ Nor should this project be interpreted as part of the ascetic ideal whereby humankind belittles itself and displaces itself from the center (GM III: 25). To the contrary: by teaching humankind how to reclaim the value-creating powers it had erroneously projected into anthropomorphic divinities, or into the world as a whole, this method actually enhances humankind's pride and self-esteem (GS 301) and is therefore a strong weapon against the ascetic ideal.
} 


\section{The Role of Values in Nietzsche's Metaphilosophy}

of the new interpretive methodology he had already outlined in GS 109. This conclusion is supported by Nietzsche's similar reasoning about indifference and necessity in GS 109 and in BGE 9 and 22. What is interesting about these various overlaps is that Nietzsche does not mention power at all in GS 109 but rather seems to have drawn this next conclusion after he first proposed his theory of will to power in his intervening book, Thus Spoke Zarathustra. The universe, he writes in GS 109, does not want to become anything and has no drives or purposes. Similarly, Nietzsche asks the Stoics in BGE 9 to think about a being like nature, indifferent beyond measure and without purposes or preferences- to think about indifference itself as power. The character of the world as a whole, he writes in GS 109, is for all eternity chaos, but not in the sense of a lack of necessity. There are no laws in nature, he adds, only necessities. Similarly, Nietzsche writes in BGE 22, his own interpretation would reveal that nature has a "necessary" and "calculable" course, not because laws obtain in it, but because laws are absolutely lacking and because, given the tyrannically inconsiderate and relentless enforcement of claims of power, every power draws its ultimate consequences at every moment.

Obviously, there is a lot more that needs to be said here about Nietzsche's reasoning from deanthropomorphism to will to power and about the unfolding of this reasoning over the course of his philosophical career from GS to BGE. This will certainly be a controversial claim, since most scholars are convinced that Nietzsche is anthropomorphically generalizing or extending his narrow concept of human psychological will to power into the much wider nonhuman realms of biology and physics. ${ }^{61}$ For example, in her most recent discussion, Clark comments as follows on Zarathustra's claim that the "will to be master" is found in everything that lives (Z II: "Self-Overcoming"): "But this seems a clearly anthropomorphic conception of life, the projection of the human will to power onto nonhuman nature. Nietzsche rejects anthropomorphic conceptions of nature ..." (Clark 2019, §11).62 Similarly, as we have seen, when commenting on Nietzsche's conclusion in BGE 36 that we should strive to envision reality itself as will to power, Clark says that "the effect of the argument is an 'audacious generalization' to the whole universe of the will to power, which Nietzsche originally understands as one human drive among others" (Clark 2019, \$11).63

However, if my analysis in this essay is correct, these interpretive claims by Clark, which are widely accepted in Nietzsche studies today, are exactly the reverse of what they should be. On the reading I've offered here, it is an enormous mistake to think that Nietzsche takes himself to be generalizing or extending his psychological concept of will to power into the wider nonhuman realms of biology and physics. What he is actually doing instead, he says, is using his new method of subtracting previous anthropomorphisms to show that

\footnotetext{
${ }^{61}$ Cf. especially Soll 2012, 119-121; 2015, 428.

${ }^{62}$ In her reply to Richardson, Clark makes the following caveat: "[T]his does not mean that when Nietzsche says that life is will to power, he is talking about the human will to power rather than about biological life. He is talking about biological life, on my view, but is doing so in terms of a metaphor derived from-and having literal application to-human life. By presenting life in terms of this metaphor, he celebrates the human will to power and gives us a vision of life from the viewpoint of his values" (Clark 2000, 119).

${ }_{33}$ In Loeb 2015, I criticize the common assumption, endorsed here by Clark, that in BGE 36 Nietzsche is offering an argument for the truth of cosmological will to power. Instead, I show, BGE 36 proposes a thought-experiment whereby we can attempt to imaginatively envision this truth - a truth that Nietzsche takes already to have been established through his subtraction argument in the previous sections of BGE.
} 
the world as a whole is will to power. ${ }^{64}$ This means that Nietzsche in no way thinks that will to power is an essentially human activity, much less a merely psychological activity. Instead, he claims that his new method reveals how will to power characterizes all inorganic nonliving activity and also all of the organic living activity that has branched off from this inorganic activity (BGE 36). Since organic life includes in turn all animal activity, which in turn includes all human activity, he thinks it follows that will to power also characterizes all human activity - an activity which according to Nietzsche is for the most part physiological rather than psychological. In particular, he argues, the psychological activity that we call "will" needs to be reconceptualized as a matter of command and obedience, that is, in terms of the tyrannically ruthless and relentless imposition of power claims that characterizes the world as a whole (BGE 19).

Put another way, scholars today are agreed that Nietzsche is pursuing a naturalistic project in which we humans are translated back into nature (BGE 230). But what they usually fail to notice is that in GS 109 Nietzsche explains that what he means by "nature" is nature that has been purified of all anthropomorphic admixture. In an important contemporaneous note, he writes: "My task: the deanthropomorphizing (Entmenschung) of nature and then the naturalizing (Vernatürlichung) of humans, after they have recovered the pure concept "nature" (KSA 9 11:[211]). ${ }^{65}$ For example, as an heir of Darwin, Nietzsche wants us to accept and understand the naturalistic truth that humans are kinds of animals who are motivated by animalistic — that is, "inhuman" or "nonhuman"-instincts and drives (A 14; cf. Richardson 2004). This is why he explains at the start of BGE that the greatest part of essentially human psychological activity, such as conscious thought and reasoning, is secretly directed by the kinds of physiological traits and instincts that are required for the preservation of our particular type of organic animal life. And then in BGE 22 and 36 he explains further that all relations among human psychological drives, and even the greatest part of those physiological activities that belong essentially to organic animal life (such as the organic functions of self-regulation, assimilation, nutrition, excretion, metabolism, and procreation), are themselves secretly directed by the tyrannically ruthless and relentless imposition of the same kind of power-claims that characterize all of nonliving inorganic nature.

Again, I recognize that this last point is highly controversial and needs a lot more discussion. Indeed, Clark even says that she finds it hard not to agree with Brian Leiter that, taken at face value, Nietzsche's theory of cosmological will to power constitutes a "crackpot metaphysics" (Clark and Dudrick 2014, 367n. 38). However, my chief goal in this essay has not been to explain or defend this theory, but rather to show how we might gain new insight into the meaning of his metaphilosophical lessons at the start of BGE by looking at the way in which he relates them to this theory. Clark's reading of these lessons is prima facie plausible and has gained widespread acceptance in the Anglophone community of Nietzsche scholars. Nevertheless, I hope I have shown that there are severe problems with her supporting textual evidence and that we should therefore reconsider

${ }^{64}$ Like most commentators, Soll does not notice Nietzsche's new subtraction argument. This is why he claims that "the truth or plausibility of the psychological thesis does not depend on the truth of the general [cosmological] thesis" and that "there is no comparable argumentation or support offered for the cosmological thesis of the will to power" (2012, 120).

${ }^{65}$ In Loeb 2021, I argue against Leiter that this replicable methodology is actually the heart of Nietzsche's philosophical naturalism and the basis of his anti-realism about values (including his own). 
how we usually think today about the role of values in Nietzsche's conception of philosophy and about the epistemic status that he grants to his own philosophical theories such as the cosmological will to power. ${ }^{66}$

\section{Works Cited}

Acampora, Christa Davis and Keith Ansell Pearson. Nietəsche's Beyond Good and Evil: A Reader's Guide. Continuum, 2011.

Anderson, R. Lanier. "Overcoming Charity: The Case of Maudemarie Clark's Nietzsche on Truth and Philosophy.” Nietzsche Studien 25 (1996): 307-341.

. "Nietzsche's Will to Power as a Doctrine of the Unity of Science." Angelaki: Journal of the Theoretical Humanities 10:1 (2005): 77-93.

Clark, Maudemarie. "Nietzsche's Doctrines of the Will to Power.” Nietzsche-Studien 12 (1983): 458-468. . Nietzsche on Truth and Philosophy. Cambridge University Press, 1990.

. "Nietzsche's Doctrine of the Will to Power: Neither Ontological nor Biological." International Studies in Philosophy 32:3 (2000): 119-135.

"Perspectivism and Falsification Revisited: Nietzsche, Nehamas, and Me." The Journal of Nietzsche Studies 49:1 (2018): 3-30.

"Nietzsche, Friedrich (1844-1900)." Routledge Encyclopedia of Philosophy (Taylor and Francis, viewed 5 June 2019), <https://www.rep.routledge.com/articles/biographical/nietzsche-friedrich1844-1900/v-1>. doi:10.4324/9780415249126-DC057-1

. Nietzsche on Ethics and Politics. Cambridge University Press, 2015.

Clark, Maudemarie and David Dudrick. The Soul of Nietæsche's Beyond Good and Evil. Cambridge University Press, 2012.

. "In Defense of an 'Esoteric' Nietzsche." Journal of the History of Philosophy 52:2 (2014): 353-369.

. "Defending Nietzsche's Soul: Response to Symposium on The Soul of Nietzsche's Beyond Good and Evil' (JNS, Vol. 45.1)," Journal of Nietzsche Studies 45:3 (2014a): 331-355.

D'Iorio, Paolo. "The Eternal Return: Genesis and Interpretation." Lexicon Pbilosophicum: International Journal for the History of Texts and Ideas 20 (2014): 41-96.

Janaway, Chris. Beyond Selflessnes: Reading Nietzsche's Genealogy. Oxford University Press, 2007.

Lampert, Laurence. Nietzsche's Task: An Interpretation of Beyond Good and Evil. Yale University Press, 2001.

Leiter, Brian. "Nietzsche's Naturalism Reconsidered." In The Oxford Handbook of Nietzssche, eds. Ken Gemes and John Richardson, 576-598. Oxford University Press, 2013.

. "The History of Philosophy Reveals that 'Great' Philosophy is Disguised Moral Advocacy: A

Nietzschean Case against the Socratic Canon in Philosophy." In Philosopby and the Historical Perspective, eds. Marcel Van Ackeren and Lee Klein, 185-199. Oxford University Press, 2018.

Loeb, Paul S. The Death of Nietzsche's Zarathustra. Cambridge University Press, 2010.

. "Will to Power and Panpsychism: A New Exegesis of Beyond Good and Evil 36." In Nietzsche on

Mind and Nature, eds. Manuel Dries and Peter Kail, 57-88. Oxford University Press, 2015.

. "Genuine Philosophers, Value-Creation, and The Will to Power: An Exegesis of Section 211

of Beyond Good and Evil." In Nietzsche's Metaphilosophy: The Nature, Method, and Aims of Philosophy, eds.

Paul S. Loeb and Matthew Meyer, 83-105. Cambridge University Press, 2019.

"Review of Brian Leiter, Moral Psychology with Nietssche," Journal of the History of Philosophy 59:1

(2021): 160-161.

Katsafanas, Paul. "On Homuncular Drives and the Structure of the Nietzschean Self," The Journal of

Nietzsche Studies 45:1 (2014): 1-11.

Meyer, Matthew. Reading Nietzsche through the Ancients. Walter de Gruyter, 2014.

Owen, David. "Is there a Doctrine of Will to Power?" International Studies in Philosophy 32:3 (2000): 95106.

Reginster, Bernard. The Affirmation of Life: Nietzsche on Overcoming Nibilism. Harvard University Press, 2006.

${ }^{66}$ Thanks to Paul Katsafanas, Scott Jenkins, Matthew Meyer, and Mark Migotti for their helpful feedback on earlier drafts of this essay. I am also grateful to the Philosophy Department at the University of Calgary for their questions and comments on the ideas in this essay. 
Riccardi, Mattia. "Review of Maudemarie Clark and David Dudrick, The Soul of Nietssche's Beyond Good and Evil," Notre Dame Philosophical Reviews, 2012.

Richardson, John. "Clark on Will to Power.” International Studies in Philosopby 32:3 (2000): 107-117. Nietzsche's New Darwinism. Oxford University Press, 2004.

"Nietzsche on Life's Ends." In The Oxford Handbook of Nietzsche, eds. Ken Gemes and John Richardson, 756-783. Oxford University Press, 2013.

Salomé, Lou. Nietzsche. Translated and edited by Siegfried Mandel. University of Illinois Press, 2001.

Schacht, Richard. "Nietzsche's 'Will to Power'.” International Studies in Philosophy 32:3 (2000): 83-94.

. "Clark and Dudrick's New Nietzsche." Journal of the History of Philosophy 52:2 (2014): 339-352.

Soll, Ivan. "Nietzsche's Will to Power as a Psychological Thesis." The Journal of Nietzsche Studies 43:1 (2012): 118-129.

. "Nietzsche Disempowered: Reading the Will to Power out of Nietzsche's Philosophy." The Journal of Nietzsche Studies 46:3 (2015): 425-450. 